\title{
Ultra-high temperature metamorphism in the Guaxupé Complex: a lower crust segment
}

\author{
Thaís Güitzlaf Leme ${ }^{*} \mathbb{D}$, Guillermo Rafael Beltran Navarro $\mathbb{D}$, Antenor Zanardo $\mathbb{D}$
}

\begin{abstract}
The area is located at the northern boundary of the Guaxupé Complex, which corresponds to the northern domain of the Socorro-Guaxupé Nappe, in the Southern Brasília Orogen, close to the Varginha Shear Zone. This study integrates petrography, mineral chemistry, optimized geothermobarometry, and trace elements thermometry data, aiming to define and characterize the metamorphic conditions and the $P-T$ path of the granulitic rocks from the northern portion of the Guaxupé Complex. In the area, the Guaxupé Complex consists predominantly of ortho-derived rocks represented by granulitic gneisses (orthopyroxene gneisses) of felsic to mafic composition with clinopyroxene, garnet, amphibole, biotite, and rare rutile. The calculated pressure and temperature conditions record metamorphic peak around $1,078^{\circ} \mathrm{C}$ and $14.8 \mathrm{kbar}$, compatible with ultra-high temperature metamorphism conditions, marked by grt $+\mathrm{cpx}+\mathrm{opx}+\mathrm{pl} \pm \mathrm{qtz} \pm \mathrm{rt}$ mineral assemblages, and granulite facies re-equilibration in the sillimanite stability field at $P$-T conditions of 930 to $800^{\circ} \mathrm{C}$ and 13.5 to $11.0 \mathrm{kbar}$. The results are compatible with deeper portions of the lower crust involved in a continental collision and suggest a clockwise $P-T$ path, typical of crustal thickening zones, followed by near-isothermal decompression during tectonic exhumation.
\end{abstract}

KEYWORDS: Southern Brasília Orogen; Guaxupé Complex; Granulites; UHT metamorphism; lower crust.

\section{INTRODUCTION}

Orogens record tectono-metamorphic processes that affected continental crust rocks at convergent plate boundaries. The roots of ancient orogens carry fundamental information on deep portions of the crust, which can be used to understand and reconstruct the geodynamic evolution of a region by unraveling the pressure-temperature-time-deformation (P-T-t-d) path (Brown 2007, Pauly et al. 2016).

Ultra-high temperature (UHT) metamorphism is a subdivision of granulite facies metamorphism and is defined as crustal metamorphism at temperatures above $900^{\circ} \mathrm{C}$ and pressures not exceeding the sillimanite stability field (Harley 1998, 2008, 2016, Brown 2007, Kelsey and Hand 2015).

UHT metamorphism provides evidence that tectonic processes may operate under extreme thermal conditions. Identifying and obtaining accurate quantitative $P-T$ conditions and $P-T$ metamorphic history of rocks that attained extreme conditions is crucial to provide valuable insights into the tectono-metamorphic settings, tectonic processes in

\footnotetext{
Supplementary data

Supplementary data associated with this article can be found in the online version: Supplementary Table.

${ }^{1}$ Universidade Estadual Paulista "Júlio de Mesquita Filho" - Rio Claro (SP), Brazil. E-mails: thais.g.leme@unesp.br, guillermo.navarro@unesp. br; antenor.zanardo@unesp.br

${ }^{*}$ Corresponding author.
}

(C) 2020 The authors. This is an open access article distributed under the terms of the Creative Commons license.
UHT granulitic terranes and implications for crust evolution (Harley 1998, 2004, 2008, 2016, Brown 2007, Kelsey 2008, Kelsey and Hand 2015). However, identify the metamorphic peak conditions of UHT granulitic terranes is potentially hampered by the application of conventional element exchange geothermobarometry, due to diffusional resetting during cooling, significantly modifying their compositions (Moraes et al. 2015, Pape et al. 2016).

In the Southern Brasília Orogen, central-south Brazil, the Guaxupé Nappe comprises granulitic terranes that record high to ultra-high temperature metamorphism conditions (Iyer et al. 1996, Campos Neto and Caby 1999, 2000, Del Lama et al. 2000, Garcia and Campos Neto 2003, Nascimento 2010, Nascimento and Oliveira 2012, Rocha et al.2017, 2018, Tedeschi et al. 2018, Leme 2019).

In order to refine the $P-T$ conditions and the $P-T$ path of Guaxupé Complex granulites, this contribution highlights more recent geothermobarometric methods applied to granulites bearing grt-opx-cpx \pm rt of the Guaxupé Complex northern portion. This approach includes optimized geothermobarometry (Thermocalc software and $\mathrm{Al}$-orthopyroxene thermobarometry) and the first data of Zr-in-rutile thermometry in ortho-derived granulitic rocks of the region. This study integrates petrography, mineral chemistry, optimized geothermobarometry, and trace elements thermometry data, aiming:

- to define and characterize the metamorphic conditions and the $P-T$ path of the granulitic rocks from the Guaxupé Complex northern portion;

- to contribute to discussions about the tectono-metamorphic evolution of the Southern Brasília Belt. 


\section{GEOLOGICAL SETTING}

The Brasília Belt comprises an orogenic system located in the eastern portion of the Tocantins Structural Province (central Brazil), extending for more than $1,200 \mathrm{~km}$ (from the central portion of Tocantins State to the NE portion of São Paulo State), along the western margin of the São Francisco Craton and is oriented to NS and NNE-SSW direction. This orogenic system results from the convergence of the Amazonian, São Francisco and Paranapanema paleocontinents during the West
Gondwana amalgamation, Brasiliano-Pan African Event, in the Neoproterozoic (Brito Neves et al. 1999, 2014, Dardenne 2000, Alkmim et al. 2001, Cordani et al. 2003, Fuck et al. 2017, Valeriano 2017) (Fig. 1).

The Brasília Belt is segmented into two orientation domains and metamorphic-deformational styles (Valeriano et al.2004, 2008, Fuck et al. 2017, Valeriano 2017), Northern Brasília Belt (NE-oriented) and Southern Brasília Belt (NW-oriented), where the study area is located.

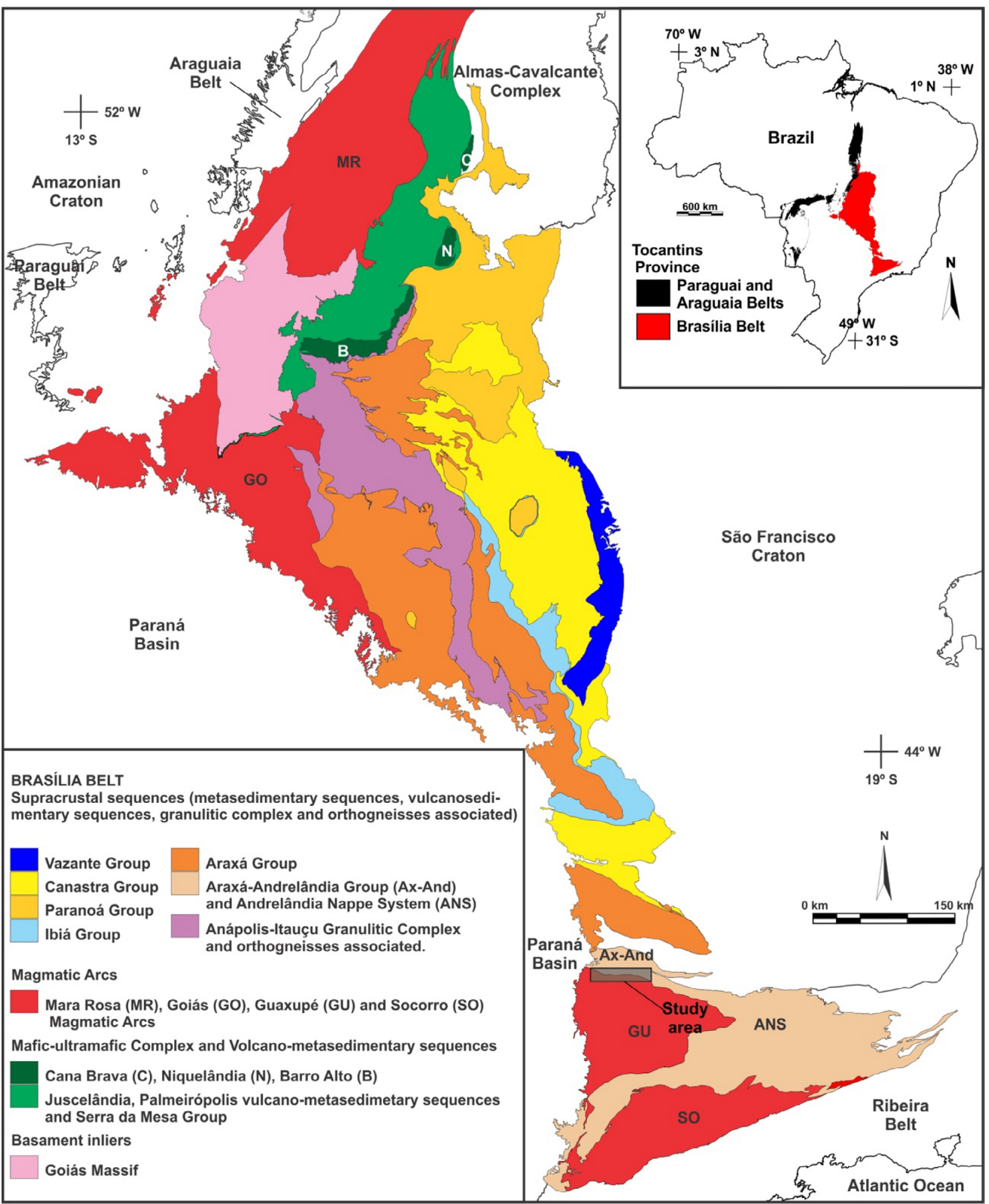

Source: modified from Heineck et al. (2004), Lacerda Filho et al. (2004), Leite et al. (2004), Souza et al. (2004), Valente et al. (2004), Brito Neves et al. (2014). Figure 1. Map showing the tectonic units that compose the Brasília Belt. 
The Southern Brasília Belt results from the Neoproterozoic collision between the active margin of the Paranapanema Block and the passive margin of the São Francisco paleocontinent, which involved subduction and collisional orogeny, and comprises a tectonic stack of E-verging nappes (Campos Neto and Caby 1999, 2000, Trouw et al. 2000, 2013, Valeriano et al. 2004, 2008, Mantovani and Brito Neves 2005, 2009, Valeriano 2017). Each nappe system represents a lithostructural domain with distinctive tectono-metamorphic features, including from WSW to ENE:

- Socorro-Guaxupé Nappe (SGN), represented by a magmatic arc domain (Campos Neto and Caby 1999, 2000, Trouw et al. 2000, 2013, Mora et al. 2014);

- Andrelândia Nappe System, including strongly deformed metasedimentary units related to an accretionary prism (Campos Neto and Caby 1999, Campos Neto et al.2010,2011);

- Carrancas and Lima Duarte Nappes System, represented by a domain related to the passive continental margin of the São Francisco Craton (Trouw et al. 2000, 2013, Campos Neto et al. 2010, 2011).

The SGN represents a thick section of the lower continental crust, interpreted according to some authors, as the root of a magmatic arc developed on the active margin of the Paranapanema Plate (Campos Neto and Figueiredo 1992, Campos Neto and Caby 1999, 2000, Trouw et al.2000, Campos Neto et al. 2004, Vinagre et al. 2014). The SGN consists of three units (Campos Neto and Caby 1999, 2000, Campos Neto et al. 2011, Mora et al. 2014, Tedeschi et al. 2015):

- Basal Granulite Unit, composed mainly of banded granulites with charnockitic to enderbitic leucosomes;

- Diatexite Unit, consisting of orthogneisses and metaluminous migmatites;

- Metatexite Unit, represented by paragneisses and metasedimentary migmatites.

The SGN is subdivided into two major domains by the NE-SW trending Ouro Fino Shear Zone. The northern domain and focus of this paper, Guaxupé Nappe, Guaxupé Domain, or Guaxupé Complex (the term used in this contribution - Del Lama et al. 2000, Zanardo 2003, Zanardo et al. 2006), and the southern, Socorro Nappe, Socorro Domain or Socorro Complex. The Ouro Fino Shear Zone is $300 \mathrm{~km}$ long and cuts a wide tectonic window consisting of Archean and Paleoproterozoic basement migmatitic orthogneisses (Amparo, Serra Negra and Pouso Alegre Complex) (Trouw et al. 2013, Cioffi et al. 2016, Oliveira et al. 2019) (Fig. 2).

The Guaxupé Complex is composed of intermediate to acidic ortho-derived lithologies, mainly represented by banded felsic to mafic orthopyroxene-bearing granulites, biotite, and amphibole-bearing orthogneisses, and syenogranitic to tonalitic biotite-bearing granitoids. Interleaved with the ortho-derived rocks, subordinated metasedimentary rocks (pelitic, psammitic, and carbonatic) occur (Zanardo 1992, Campos Neto and Caby, 1999, 2000, Del Lama et al. 2000, Zanardo et al. 2006).

According to Del Lama et al. (2000), the Guaxupé Complex can be divided into three domains based on pressure variation:
- N-NE domain, represented by high-pressure grade;

- intermediate domain, with intermediate to high-pressure grade;

- S-SW domain, represented by low- to intermediate-pressure grade.

High to ultra-high temperature metamorphic conditions were determined for the Basal Granulite Unit of the Guaxupé Complex, indicating metamorphic $P-T$ peak conditions above $900^{\circ} \mathrm{C}$ and $10 \mathrm{kbar}$ (Del Lama et al. 2000, Campos Neto and Caby 2000, Nascimento 2010, Rocha et al. 2018, Tedeschi et al. 2018, Leme 2019). Similar P-T conditions were also reported for the adjacent Diatexite and Metatexite units (Rocha et al. 2017).

The study area (Fig. 2) is located in the region of Guaxupé-Guaranésia-Monte Belo cities, close to the Varginha Shear Zone (Cavalcante et al. 1979), northern boundary of the Guaxupé Complex, in the Basal Granulite Unit.

\section{ANALYTICAL METHODS}

Petrographic and mineral chemistry analyses were performed at the Department of Petrology and Metallogeny (DPM) laboratories of the Institute of Geosciences and Exact Sciences (Instituto de Geociências e Ciências Exatas - IGCE), Universidade Estadual Paulista "Júlio de Mesquita Filho" (Unesp), Rio Claro Campus.

Mineral chemistry analyses were performed using a JEOL JXA-8230 Superprobe Electron Microprobe (EPMA). Garnet, orthopyroxene, clinopyroxene, plagioclase, orthoclase, amphibole, and biotite were analyzed with an acceleration voltage of $15 \mathrm{kV}$, beam current of $20 \mathrm{nA}$, and a spot size of $10 \mu \mathrm{m}$, using minerals and synthetic oxides as standard elements. The counting time for the major elements was 10 seconds at the peak and 5 seconds for each background position; for minor elements, 20 seconds were used at the peak and 10 seconds for each background position.

Mineral activity calculations of the analyzed phases and mineral structural formulas were obtained by AX (Holland and Powell 2000) and MINPET 2.02 (Richard 1995) software, in addition to the use of structural formula calculation worksheets according to Deer et al. (1992, 1997a, 1997b, 1997c, 2004).

Rutile EPMA trace elements analyses ( $\mathrm{Si}$ and $\mathrm{Zr}$ ) were performed with an acceleration voltage of $20 \mathrm{kV}$, beam current of $80 \mathrm{nA}$, and spot size of $5 \mu \mathrm{m}$, according to the method of Luvizotto et al. (2009). Analyses with $\mathrm{Si}$ concentrations above 300 ppm were excluded, as recommended by Zack et al. (2004).

Calculations of temperature and pressure conditions were obtained by THERMOCALC, version 3.26 (avPT mode) (Powell and Holland 1994), and RCLC (Thermobarometry Corrected for Retrograde Exchange) program by Pattison et al. (2003), and by the Zr-in-rutile geothermometer, calibrated by Tomkins et al. (2007).

\section{FIELD RELATIONSHIPS}

The study area is located in the northern part of the Guaxupé Complex, to the south of the Varginha Shear Zone 


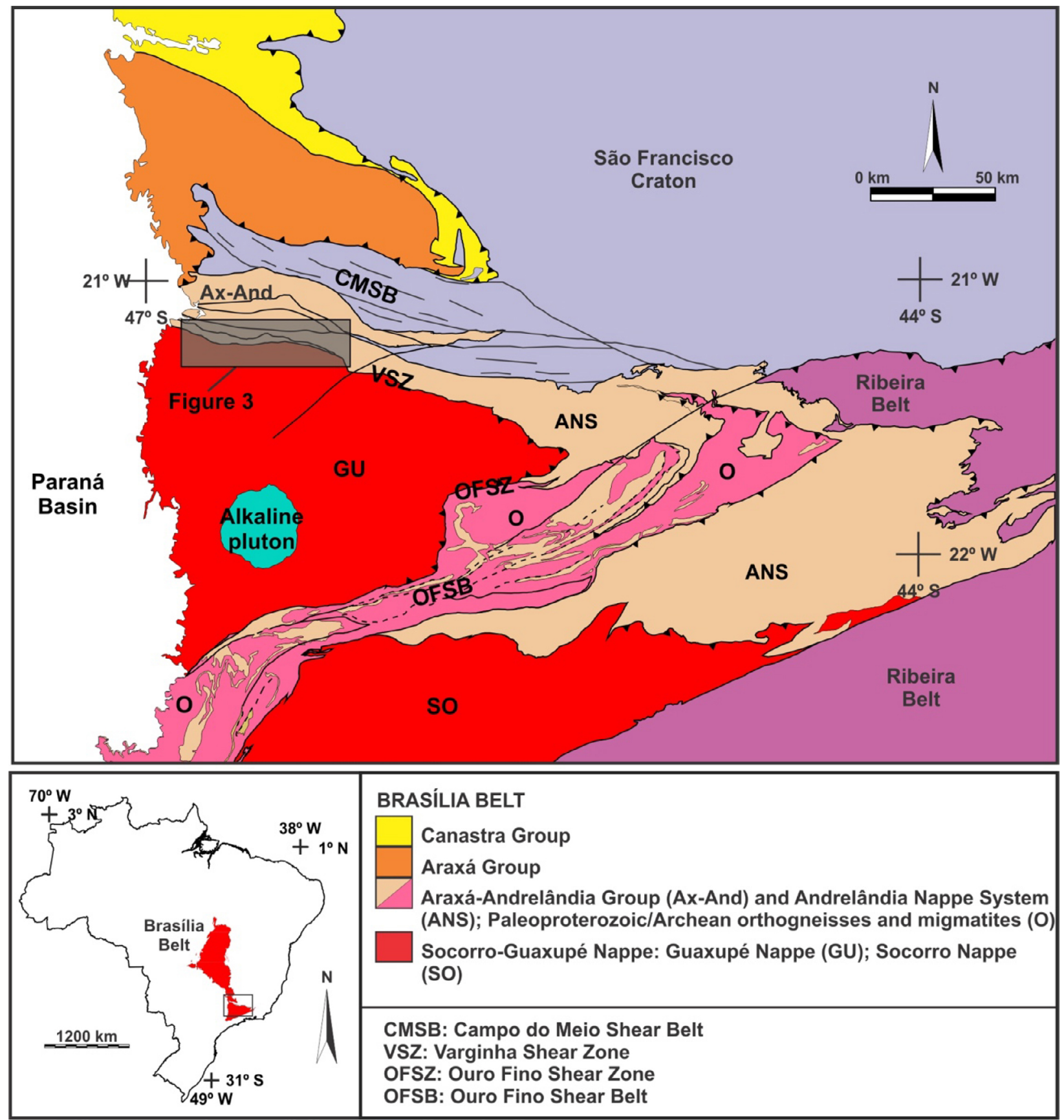

Source: modified from Fonseca et al. (1979), Zanardo (1992), Leite et al. (2004), Trouw et al. (2013).

Figure 2. Geological map highlighting the tectonic units of the Southern Brasília Belt The rectangle is the localization of Figure 3.

(VSZ), in the region of Guaxupé-Guaranésia-Monte Belo cities. The area corresponds to the northern portion of the Basal Granulite Unit of the SGN.

The VSZ delimits the northern boundary of the Guaxupé Complex and separates UHT rocks, represented by the Guaxupé Complex, to the south, from high-pressure rocks (Del Lama et al. 1994, Leme 2019, Leme et al. 2019) attributed to the Araxá Group, to the north. The sinistral transcurrent VSZ has an approximately E-W direction and inflects toward SE in the eastern part, at the height of Monte Belo municipality, where it acquires lateral ramp features (Zanardo 1992, Morales 1993, Del Lama et al. 2000).

The location of the studied samples is shown in Figure 3. In the study area, the Guaxupé Complex consists predominantly of basic to acidic ortho-derived rocks, with a prevalence of intermediate compositions, associated with rare intercalations of metasedimentary rocks, both metamorphosed at granulite facies.

Ortho-derived rocks are represented by banded to homogeneous granulitic gneisses (orthopyroxene gneisses) of felsic to mafic composition, with or without clinopyroxene, garnet, amphibole, and less often biotite and rutile associated, interlayered with granitic to tonalitic banded gneisses with amphibole and/or biotite, which may also contain garnet and clinopyroxene, and mafic granulite lenses.

The ortho-derived lithologies are fine to coarse-grained, and the gneiss banding is defined by the alternation of continuous to discontinuous layers, with variable thickness (submillimeter to subcentimeter), marked by compositional variation between felsic (quartz-feldspathic) and mafic (pyroxenes, 


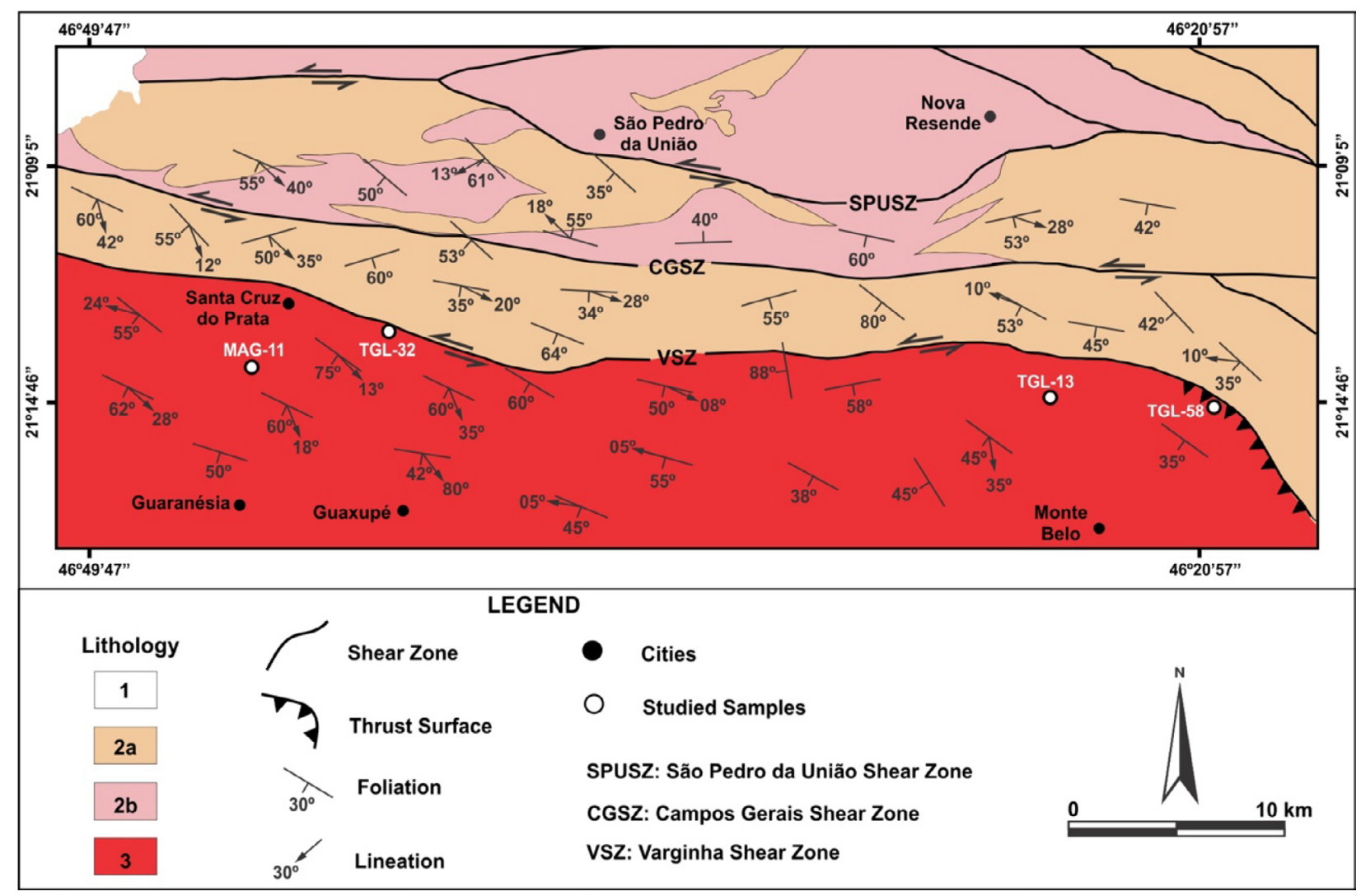

Source: modified from Zanardo (1992), Del Lama (1998), Leme (2019).

1: Paraná Basin; 2: Araxá Group; 2a: Psamo-pelitic metasedimentary sequence; 2b: Orthogneisses and granitoids; 3: Guaxupé Complex.

Figure 3. Simplified geological map showing the location of the studied samples.

amphibole, garnet, and biotite) beds. The occurrence of garnet in granulitic gneisses is more common in the northern boundary of the Guaxupé Complex, near VSZ southeast inflection, in Monte Belo region.

The metasedimentary rocks associated with this unit are subordinate in the study area. These rocks are mainly represented by fine to coarse-grained quartzites, quartz gneisses, and quartz schists bearing garnet, sillimanite, orthoclase, and rutile, and occur in discontinuous centimeter-to-metric lenses interlayered with the ortho-derived rocks; or as discontinuous metric-to-decametric bands that narrow in the granulitic gneisses.

The rocks of the Guaxupé Complex exhibit penetrative foliation with W to WNW direction, parallel to the compositional banding and with a moderate to high dip angle toward SSW. Frequently, the main foliation is blastomylonitic with different development degrees, comprising anastomosed and lenticular forms (Fig. 3).

\section{PETROGRAPHY AND MINERAL CHEMISTRY}

Based on the mineralogical and textural aspects, three samples of garnet granulitic gneiss (samples: TGL-13, TGL-32, and TGL-58) and one sample of basic granulite (sample MAG-11) were selected for mineral chemical analysis. Representative results of major element composition of garnet, clinopyroxene, orthopyroxene, feldspar, amphibole, and biotite are presented in the Supplementary Tables (Tables S.1, S.2, S.3, S.4, and S.5). Mineral abbreviations are according to Whitney and Evans (2010).

\section{Garnet granulitic gneiss}

The garnet granulitic gneiss occurs immediately to the south of the VSZ. This rock type is characterized by a predominantly intermediate composition and fine- to medium-grained. The texture is oriented and granoblastic with discontinuous porphyroblastic domains, which define the foliation (Fig. 4A).

The main mineralogy is composed of plagioclase (40-55\%), quartz (1-25\%), garnet (5-20\%), clinopyroxene (7-15\%), orthopyroxene $(5-13 \%)$, orthoclase (traces - 5\%), amphibole ( $0-10 \%)$, and biotite (0-4\%). Opaque minerals (2-3\%), apatite (traces - 1\%), zircon (traces), and rutile (0-2\%) occur as accessory minerals.

Subhedral, anhedral, and rounded garnet $\left(\mathrm{Alm}_{42-51} \operatorname{Prp}_{30}\right.$ ${ }_{39} \mathrm{Grs}_{9-17} \mathrm{Adr}_{<1-7} \mathrm{Sps}_{<1-3}$ ) occur in diffuse porphyroblastic aggregates, with grains dimensions ranging from 1.0 to $4.5 \mathrm{~mm}$. The crystals are poikilitic, with inclusions of quartz, plagioclase, opaque minerals, clinopyroxene, and less often rutile and biotite, and frequently exhibit irregular shapes with lobate boundaries (Figs. 4B, 4C, and 4D). Some crystals are corroded and replaced by clinopyroxene and orthopyroxene and secondarily by biotite. The compositional profiles are relatively flat and homogeneous, with slight chemical variations toward the crystals rims, defined by an increase in $\mathrm{Fe}^{2+}$ and a decrease in $\mathrm{Mg}$. Grossular and andradite concentrations exhibit reverse trend profiles but do not show well-defined chemical zoning. 

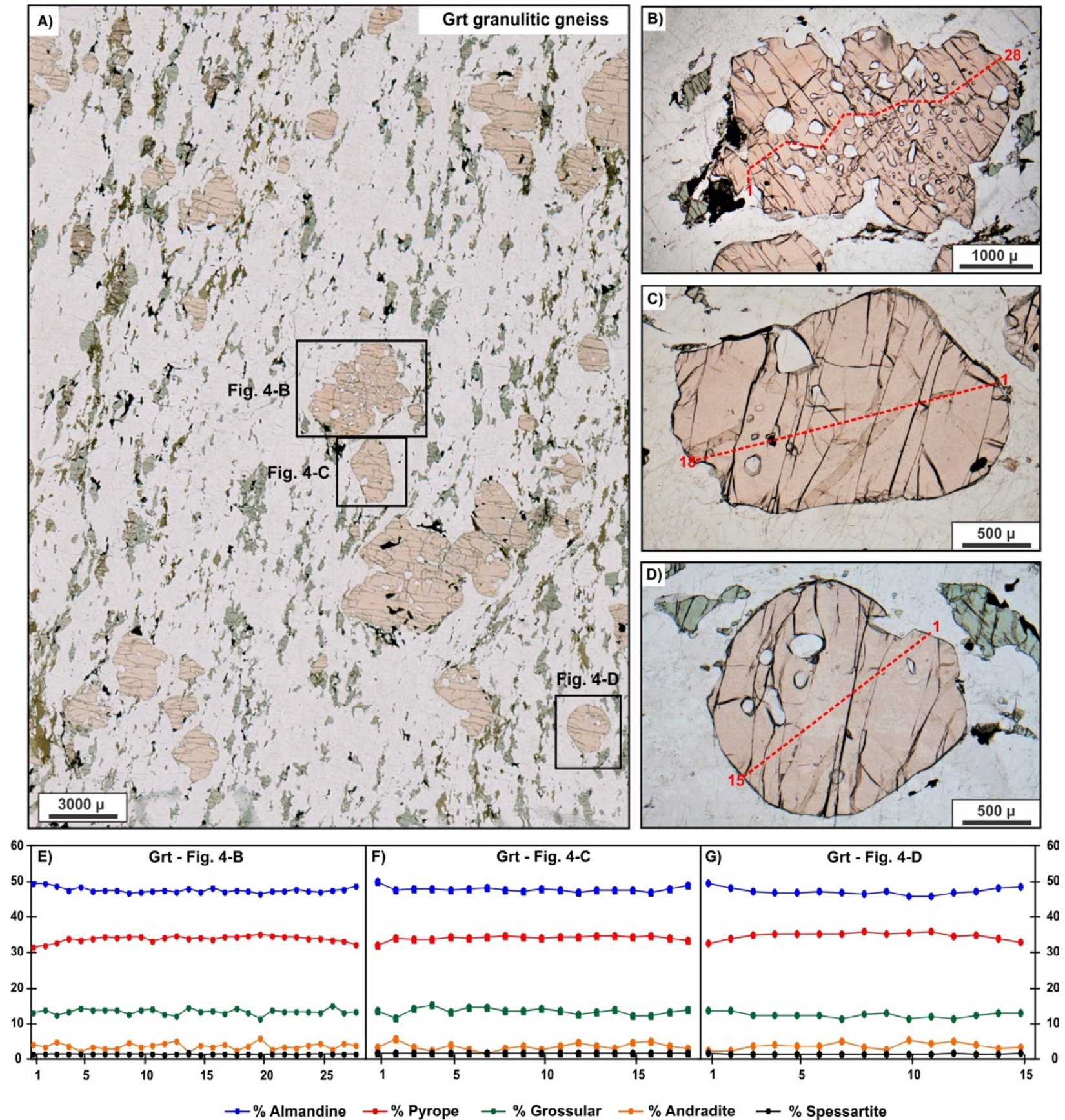

Figure 4. Mineralogical and textural aspects from garnet granulitic gneiss. (A) Photograph of thin-section of garnet granulitic gneiss (sample TGL-13), illustrating the granoblastic texture with porphyroblastic domains and the location of analyzed garnet crystals. (B, C, D) Detail of the textural aspects of garnet crystals and the location of compositional profiles. (E, F, G) Compositional profiles across garnet crystals in garnet granulitic gneiss.

Spessartite concentrations are low and homogeneous across all crystals (Figs. 4E, 4F, and 4G).

Plagioclase $\left(\mathrm{An}_{34-38}\right)$ occurs as anhedral to subhedral crystals and is commonly elongated, with polygonal to predominantly lobate boundary. The crystals may be antiperthitic or myrmekitic (Fig. 5A). Quartz forms ribbons and can reach dimensions of up to $5.0 \mathrm{~mm}$ in length (Fig. 5B). In the more mafic and plagioclasitic portions, quartz is interstitial and vermiform. Orthoclase is anhedral and occurs as interstitial crystals, forming antiperthitic texture.

Clinopyroxene is classified as sahlite $\left(\mathrm{Wo}_{39-47} \mathrm{En}_{33-39} \mathrm{Fs}_{15-20}\right)$, has $\mathrm{X}_{\mathrm{Mg}}$ content ranging from 0.58 to $0.73, \mathrm{Al}$ core content between 0.17 to 0.28 atoms per formula unit (a.p.f.u.), and
Na core content between 0.04 to 0.09 a.p.f.u. It occurs as subhedral to anhedral crystals, partially replaced by amphibole. Anhedral to rounded orthopyroxene is hypersthene $\left(\mathrm{En}_{57-62}\right)$, has $\mathrm{X}_{\mathrm{Mg}}$ content ranges from 0.58 to 0.62 and $\mathrm{Al}$ core content between 0.08 to 0.17 a.p.f.u. The crystals are partially replaced by clinopyroxene, amphibole, and biotite (Figs. 5C, 5D, and 5E).

Amphibole, where present, exhibit calcium composition $\left(\mathrm{Ca}_{B}>1.5, \mathrm{Na}_{\mathrm{A}}+\mathrm{K}_{\mathrm{A}}>0.5, \mathrm{Ti}<0.5\right.$ e $\mathrm{Si}<6.5$; Leake et al. 1997) and is classified as magnesiohastingsite. Ti content is high and ranges from 0.26 to 0.35 a.p.f.u. The crystals may be well-developed or occur as small crystals replacing the pyroxenes associated with the metamorphic re-equilibration process (Figs. 5D, and 5E). 

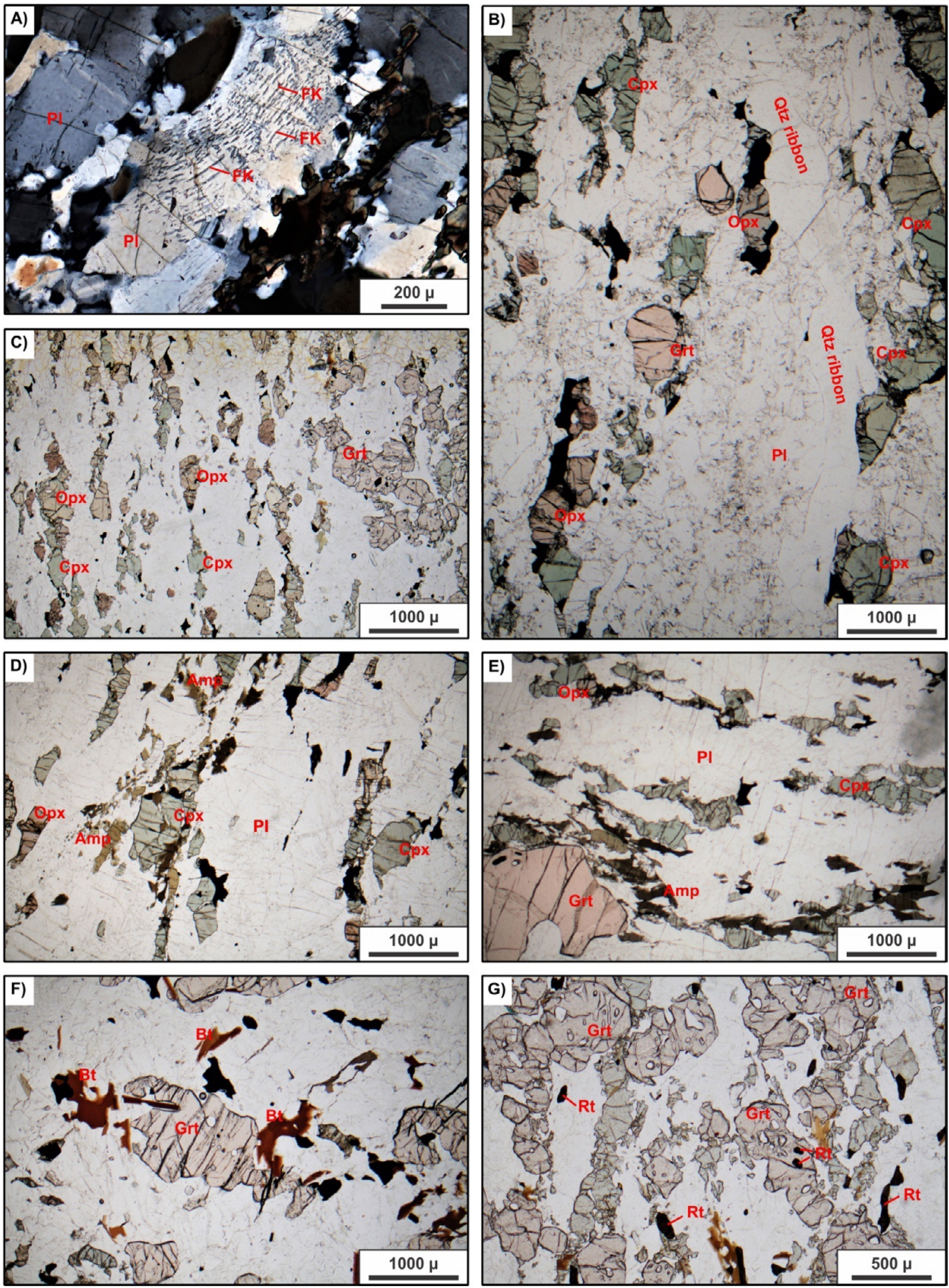

Figure 5. Representative photomicrographs showing detail of textural aspects from garnet granulitic gneiss. (A) Antiperthitic texture in plagioclase crystal (crossed polarized light) (Sample TGL-13); (B, C) Granoblastic oriented texture showing the main mineral assemblage $(\mathrm{grt}+\mathrm{cpx}+\mathrm{opx}+\mathrm{pl}$ ), with emphasis on quartz ribbons in (B) (plane polarized light) (Sample TGL-32 and Sample TGL-58, respectively); (D, E) Pyroxene crystals (cpx and opx) partially replaced by amphibole (plane polarized light) (Sample TGL-13); (F) Biotite corroding garnet crystals (plane polarized light) (Sample TGL-58); (G) Rutile inclusions in garnet and rutile grains in matrix (plane polarized light) (Sample TGL-58).

Biotite $\left(\mathrm{X}_{\mathrm{Mg}}=0.69\right.$ to 0.72$)$, where present, is classified as phlogopite $\left(\mathrm{Fe} /(\mathrm{Fe}+\mathrm{Mg}) \times \mathrm{Al}^{\mathrm{IV}}\right)$ and has composition characterized by high Ti core contents (0.60-0.64 a.p.f.u.). It is frequently associated with amphibole and garnet replacement (Fig. 5F).
Opaque minerals include ilmenite, magnetite, chalcopyrite, and pyrrhotite. Ilmenite crystals occur with exsolution lamellae of magnetite. Rutile is rare and occurs in garnet granulitic gneiss in the northern portion of the Guaxupé Complex, close to the VSZ inflection. It occurs as subprismatic to anhedral 
crystals, with dimensions up to $0.3 \mathrm{~mm}$, associated with mafic minerals, dispersed in quartz-feldspathic granoblastic beds, or included in garnet crystals (Fig. 5G). Rutile crystals are clear and homogeneous (Figs. 6A, and 6B) or may have exsolution lamellae of ilmenite (Figs. 6C, and 6D).

\section{Basic granulite}

Basic granulites occur as metric lenses interlayered with granulitic gneisses and garnet granulitic gneisses. This rock type exhibits massive structure with incipient to prominent orientation and decussate granoblastic texture domains with euhedral amphibole and clinopyroxene crystals, to nematoblastic domains (Fig. 7A). The mineralogy consists of amphibole $( \pm 45 \%)$, clinopyroxene $( \pm 35 \%)$, plagioclase $( \pm 10 \%)$, orthopyroxene $( \pm 8 \%)$, garnet $( \pm 2 \%)$, and opaque minerals $(<1 \%)$.

Amphibole has calcium composition $\left(\mathrm{Ca}_{\mathrm{B}} \geq 1.5, \mathrm{Na}_{\mathrm{A}}+\right.$ $\mathrm{K}_{\mathrm{A}} \geq 0.5, \mathrm{Ti} \leq 0.5$ e $\mathrm{Si}<6.5$; Leake et al. 1997) and is classified as magnesiohastingsite, with $\mathrm{Ti}$ core contents ranging from 0.18 to 0.23 a.p.f.u. It occurs as euhedral to subhedral crystals with decussate texture; and also as anhedral crystals replacing pyroxene (clinopyroxene and orthopyroxene) with nematoblastic texture. Amphibole does not show compositional zoning, and chemical differences were not observed between the euhedral and anhedral crystals.
Clinopyroxene is classified as sahlite $\left(\mathrm{Wo}_{41-44} \mathrm{En}_{36-38} \mathrm{Fs}_{13-15}\right)$ and exhibits no significant core-rim compositional variation. $\mathrm{X}_{\mathrm{Mg}}$ contents range from 0.68 to $0.74, \mathrm{Al}$ core content between 0.20 and 0.26 a.p.f.u., and $\mathrm{Na}$ core content between 0.05 and 0.07 a.p.f.u. The crystals are subhedral to anhedral and may occur partially replaced by amphibole, and with orthopyroxene exsolution lamellae. Orthopyroxene is hypersthene $\left(\mathrm{En}_{63-65}\right)$, with $\mathrm{X}_{\mathrm{Mg}}$ contents ranging from 0.65 to 0.67 and $\mathrm{Al}$ core content from 0.12 to 0.18 a.p.f.u. They are frequently anhedral, replaced mainly by amphibole and, less often, by clinopyroxene (Figs. 7B, and 7C).

Plagioclase $\left(\mathrm{An}_{43-54}\right)$ occurs in discontinuous domains in tabular to anhedral shapes, with dominantly polygonal boundary. The crystals exhibit subtle compositional zoning, marked by a slight increase in $\mathrm{Ca}$ and a decrease in $\mathrm{Na}$ toward the rims of the crystals.

Garnet $\left(\mathrm{Alm}_{40-44} \operatorname{Prp}_{36-41} \mathrm{Grs}_{9-12} \mathrm{Adr}_{5-8} \mathrm{Sps}_{2-3}\right)$ is rare and occurs as anhedral to rounded crystals, with variable dimensions (from 0.3 to $4.5 \mathrm{~mm}$ ). The compositional profiles are almost flat, marked by weak chemical zoning, with an increase in $\mathrm{Fe}^{2+}$ and a decrease in $\mathrm{Mg}$ toward the crystals rims. Grossular and andradite concentrations exhibit reverse trend profiles but do not show well-defined chemical zoning. Spessartite concentrations are homogeneous and low across all crystals (Figs. 7D).
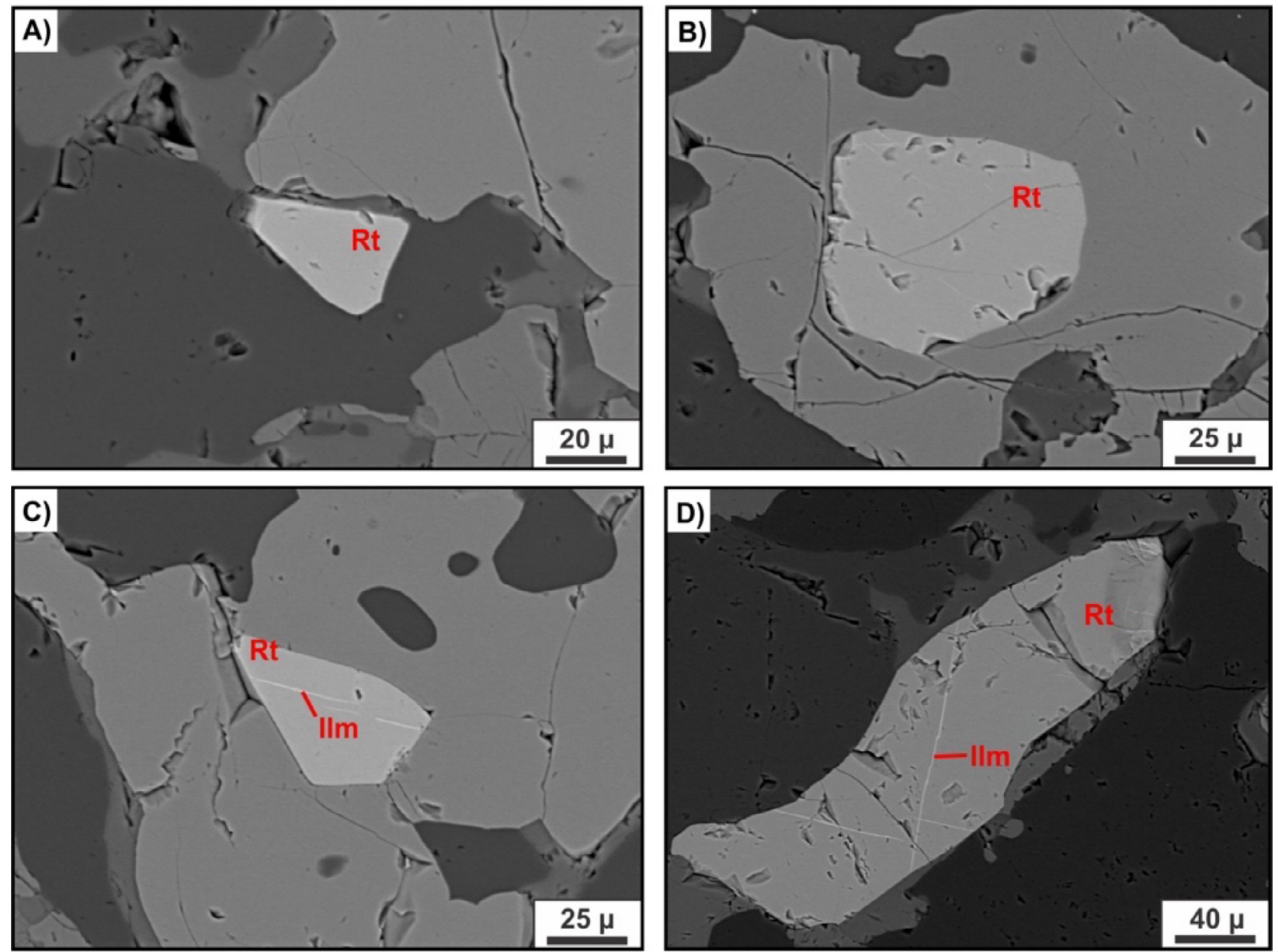

Figure 6. Back-scattered electron (BSE) images of representative rutile grains in garnet granulitic gneiss (Sample TGL-58). (A) Homogeneous anhedral rutile crystal in the rock matrix; (B) homogeneous rounded rutile inclusion in garnet; (C) anhedral rutile inclusion with thin ilmenite exsolution lamellae; (D) subhedral rutile crystal with thin ilmenite exsolution lamellae in the rock matrix. 


\section{Granulitic gneiss}

Toward the south and southwest of the Guaxupé Complex, the study area is dominated by granulitic gneisses (orthopyroxene gneisses), with oriented granoblastic texture and nematoblastic domains. The mineralogy consists of plagioclase (30-60\%), quartz (traces-20\%), potassium feldspar (1-35\%), orthopyroxene (5-10\%), clinopyroxene (0-10\%), amphibole (0-20\%), biotite $(0-5 \%)$, and opaque minerals $(2-4 \%$, in addition to apatite $( \pm 1 \%)$ and zircon (traces) (Figs. $8 \mathrm{~A}, 8 \mathrm{~B}$, and $8 \mathrm{C}$ ).

Plagioclase (oligoclase and andesine) has subhedral to anhedral shapes and is commonly elongated, with lobate to polygonal boundary. The crystals may be myrmekitic or antiperthitic and dimensions range from 0.1 to $3.0 \mathrm{~mm}$.
On the acidic and intermediate terms, quartz occurs as ribbons up to $4.5 \mathrm{~mm}$ in length. It may have a very restricted occurrence in more plagioclasitic and basic terms, with interstitial disposition.

Potassium feldspar (orthoclase and microcline) is elongated and has subhedral to anhedral shapes, with dimensions up to $5.0 \mathrm{~mm}$. The crystals exhibit perthitic to mesoperthitic texture, with lobate boundary.

Orthopyroxene is subhedral to anhedral, commonly elongated, with dimensions ranging from 0.2 to $2.0 \mathrm{~mm}$. The crystals occur partially replaced by amphibole or exhibit exsolution lamellae of clinopyroxene. Where present, anhedral to subhedral diopside crystals occur with dimensions of up to $4.0 \mathrm{~mm}$
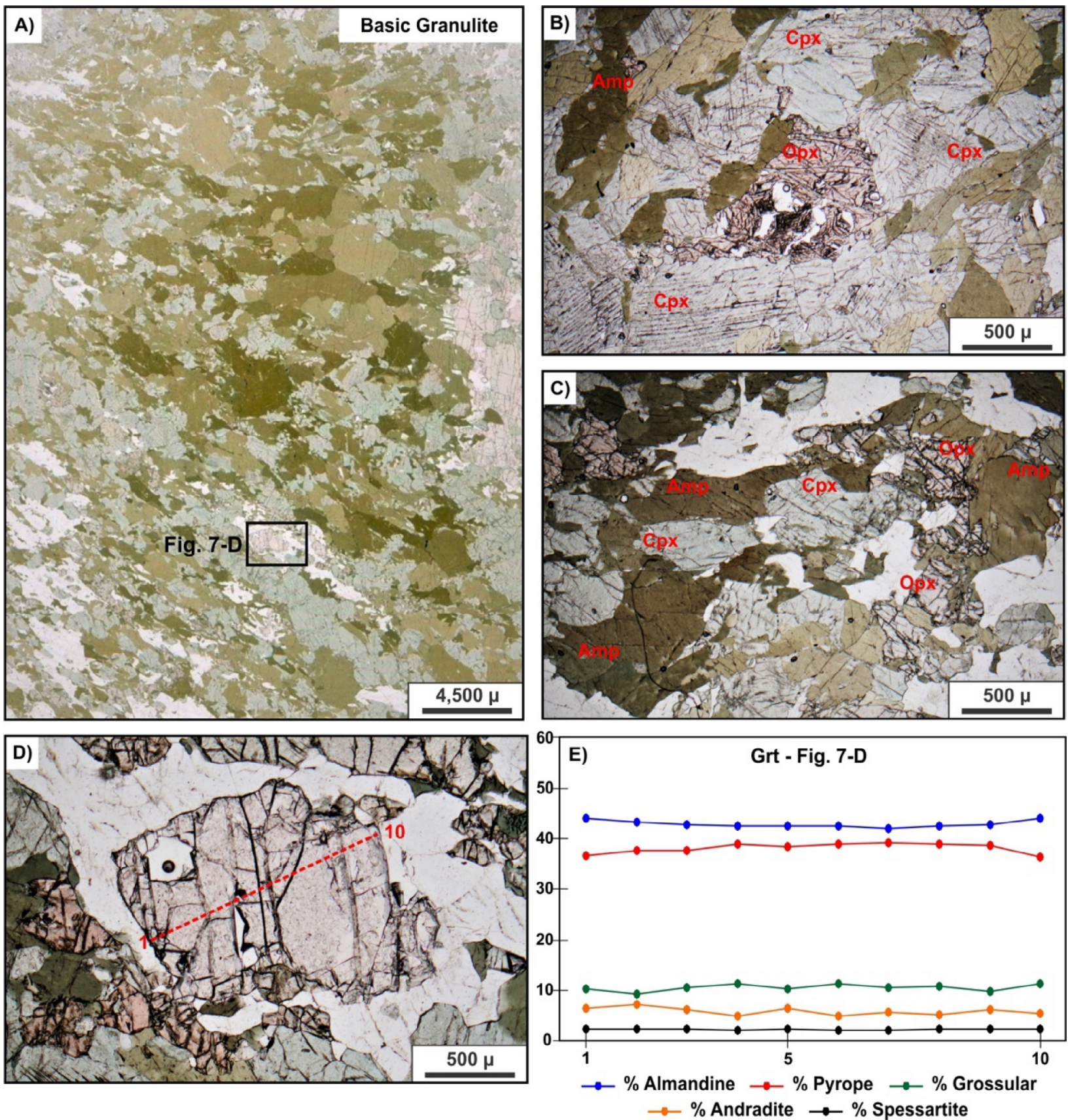

Figure 7. Mineralogical and textural aspects from basic granulite (Sample MAG-11). (A) Photograph of thin-section of basic granulite, illustrating the granoblastic texture, mineral assemblage and the location of analyzed garnet crystal; (B, C) pyroxene crystals (cpx and opx) partially replaced by amphibole (plane polarized light); (D) detail for garnet texture showing the location of compositional profile (plane polarized light); (E) compositional profile across garnet. 

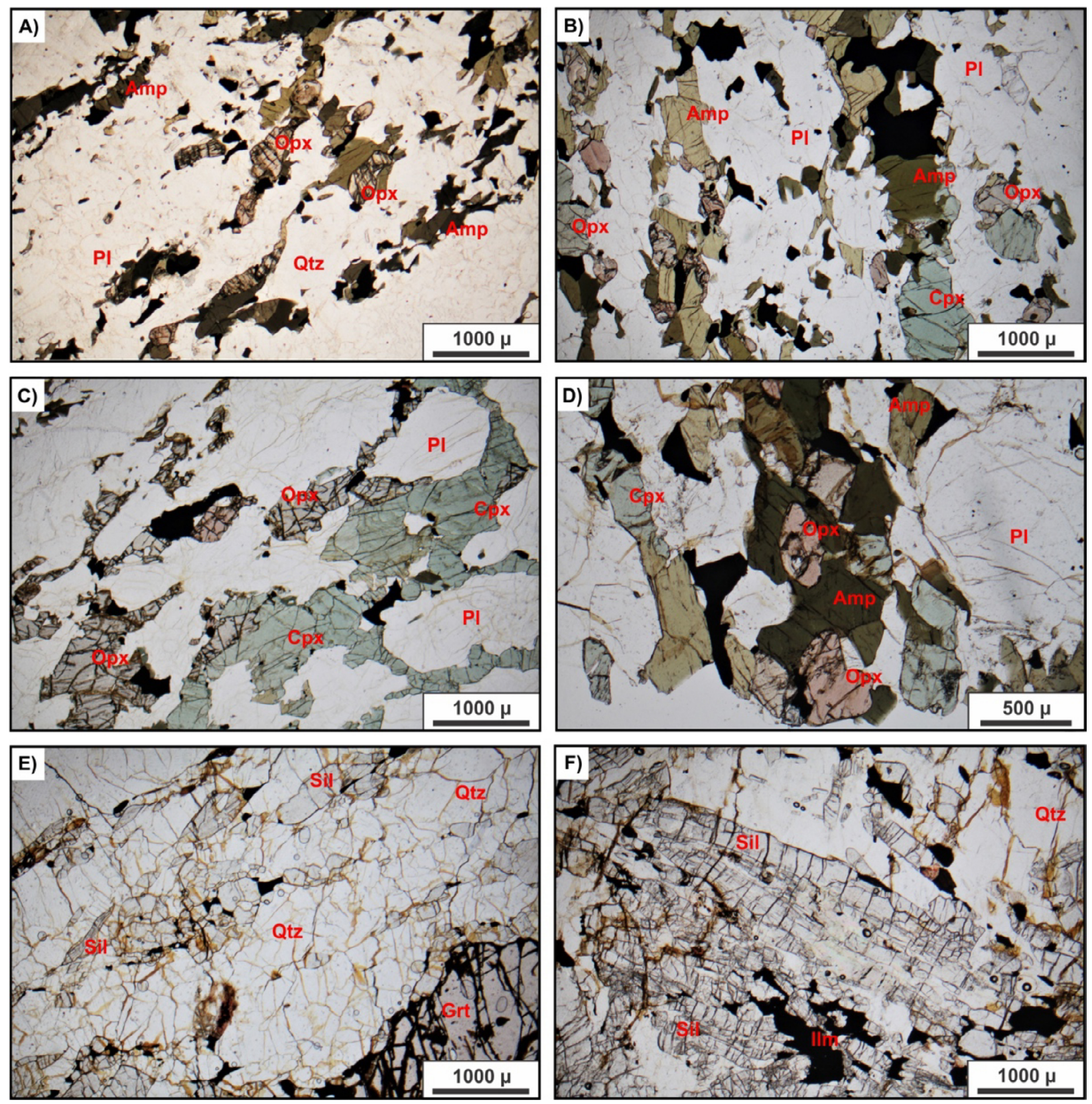

Figure 8. Representative photomicrographs showing detail of textural aspects and mineral assemblage from granulitic gneiss and metasedimentary rocks. (A, B, C) Oriented granoblastic texture consisting of quartz-feldspathic beds and granoblastic/nematoblastic domains composed of mafic minerals (opx, cpx, and amp) (plane polarized light); (D) orthopyroxene crystals partially replaced by amphibole (plane polarized light); (E) oriented granoblastic to porphyroblastic texture with discontinuous oriented nematoblastic domains composed of sillimanite (plane polarized light); (F) aggregates of prismatic sillimanite crystals associated with ilmenite (plane polarized light).

and may be partially replaced by amphibole or orthopyroxene, and may exhibit exsolution lamellae of orthopyroxene.

Hornblende occurs as well-developed subhedral crystals up to $3.0 \mathrm{~mm}$ in length, or as medium-sized anhedral crystals in order of $0.4 \mathrm{~mm}$, associated with pyroxene replacement (Fig. 8D). In some portions, amphibole crystals show equilibrium texture with pyroxenes. Brownish biotite occurs as a result of amphibole and pyroxene replacement.

\section{Metasedimentary rocks}

Metasedimentary rocks show inequigranular oriented granoblastic to porphyroblastic texture, with discontinuos nematoblastic domains. This rock type is composed of quartz (50-65\%), garnet (15-30\%), potassium feldspar (0-25\%), sillimanite (10-15\%), biotite (traces-5\%), muscovite (0-3\%), and accessory mineralogy composed of rutile $(<1-2 \%)$, opaque minerals $(<1-3 \%)$, zircon $(<1 \%)$, and apatite $(<1 \%)$ (Fig. $8 \mathrm{E})$.

Quartz has an anhedral shape, is elongated and exhibits a high degree of recrystallization. Anhedral to rounded garnet crystals range in size from 2.0 to $8.0 \mathrm{~mm}$ and are poikilitic, with inclusions of opaque minerals, rutile, sillimanite, quartz, and biotite. Sillimanite has prismatic to anhedral shape, with dimensions ranging from less than 0.1 to $3.0 \mathrm{~mm}$, and occurs concentrated in discontinuous domains, forming oriented lenticular aggregates with strong undulose extinction (Fig. 8F). Rutile crystals occur included in garnet crystals, dispersed in quartz granoblastic beds, or associated with sillimanite crystals and opaque minerals. Biotite and muscovite occur as 
small tabular crystals resulting from the replacement of garnet and sillimanite.

\section{P-T CONDITIONS OF METAMORPHISM}

High-grade metamorphism conditions were calculated by optimized geothermobarometry using THERMOCALC and RCLC software, both using an internally consistent thermodynamic database to calculate pressure and temperature conditions. The same combined analyses of garnet, orthopyroxene, plagioclase, and biotite were used for the calculations by the Average $P$-T and Al-solubility in orthopyroxene methods.

\section{Thermocalc (average P-T)}

The pressure and temperature results obtained for each sample and the mineral assemblage used for the calculation are presented in Table 1. Average P-T calculations for the garnet granulitic gneiss (samples TGL-13, TGL-32, and TGL-58) were performed with and without orthoclase in the mineral assemblage. The calculations for hydrated mineral assemblage were obtained with $a_{\mathrm{H} 2 \mathrm{O}}$ values of 0.3 , which resulted in the smallest uncertainties.

For garnet granulitic gneiss with amphibole (sample TGL-13), the mineral assemblage considered was sahlite + hypersthene + almandine + andesine $+\mathrm{Mg}$-hastingsite + quartz \pm orthoclase. In calculations in which orthoclase is not considered, average $P-T$ values range from $11.3 \pm 0.70$ to $12.8 \pm$ $0.50 \mathrm{kbar}$ and from $957 \pm 27$ to $968 \pm 30^{\circ} \mathrm{C}$, with correlations of the order of 0.5 (Fig. 9A, Tab. 1). Considering potassium feldspar in the mineral assemblage, the $P-T$ conditions are slightly lower and more homogeneous, ranging from $11.3 \pm 0.7$ to 11.6 $\pm 0.7 \mathrm{kbar}$ and from $887 \pm 36$ to $900 \pm 37^{\circ} \mathrm{C}$ (Fig. 9A, Tab. 1).

For garnet granulitic gneiss (sample TGL-32) without amphibole or biotite, the mineral assemblage used was sahlite + hypersthene + almandine + andesine + quartz \pm orthoclase In orthoclase-free calculations, pressure and temperature values range from $13.8 \pm 1.5$ to $14.7 \pm 1.30 \mathrm{kbar}$ and from $1,108 \pm 121$ to $1,199 \pm 99^{\circ} \mathrm{C}$, with high correlations (Fig. 9B, Tab. 1). For potassium feldspar-bearing assemblages, the $P$ - $T$ results range from $12.7 \pm 1.30$ to $14.6 \pm 1.60 \mathrm{kbar}$ and from $988 \pm 98$ to $1,124 \pm 114^{\circ} \mathrm{C}$, with high correlations (Fig. 9B, Tab. 1).

In garnet granulitic gneiss with biotite, amphibole, and rutile (sample TGL-58), the mineral assemblage considered was sahlite + hypersthene + almandine + andesine + Mg-hastingsite + phlogopite + quartz \pm orthoclase. Calculations in which orthoclase is not used indicate pressure and temperature values from $12.0 \pm 0.90$ to $12.7 \pm 1.0 \mathrm{kbar}$ and from $928 \pm 28$ to $979 \pm 43^{\circ} \mathrm{C}$, with correlations ranging from 0.47 to 0.63 (Fig. 9C, Tab. 1). Considering potassium feldspar in the calculation, the average $P-T$ is slightly lower and more homogeneous and ranges

Table 1. $P$ - $T$ conditions calculated by THERMOCALC software (Average $P-T$ ).

\begin{tabular}{|c|c|c|c|}
\hline Sample & Mineral assemblage & $\mathbf{P}($ Kbar $) / \mathbf{T}\left({ }^{\circ} \mathbf{C}\right)$ & Correlation \\
\hline TGL-13 & $\mathrm{Pl}_{4 \_6} \mathrm{Grt}_{8 \_14} \mathrm{Cpx}_{7 \_1} \mathrm{Opx}_{3 \_3} \mathrm{Amp}_{2_{-} 1} \mathrm{Qtz}$ & $12.2 \pm 0.6 / 961 \pm 29$ & 0.474 \\
\hline TGL-13 & $\mathrm{Pl}_{4_{-} 1} \mathrm{Grt}_{6 \_13} \mathrm{Cpx}_{1_{-} 1} \mathrm{Opx}_{3_{-1} 1} \mathrm{Amp}_{4_{-} 1} \mathrm{Qtz}$ & $12.8 \pm 0.5 / 968 \pm 30$ & 0.499 \\
\hline TGL-13 & $\mathrm{Pl}_{7{ }_{1} 1} \mathrm{Grt}_{10 \_5} \mathrm{Cpx}_{1{ }^{-2}} \mathrm{Opx}_{5_{-} 3} \mathrm{Amp}_{4_{-} 3} \mathrm{Qtz}$ & $11.3 \pm 0.7 / 957 \pm 27$ & 0.516 \\
\hline TGL-13 & $\mathrm{Pl}_{4-6} \mathrm{Grt}_{8_{-14}} \mathrm{Cpx}_{7{ }_{-1}} \mathrm{Opx}_{3-3} \mathrm{Amp}_{2{ }_{2} 1} \mathrm{Qtz} \mathrm{Or}_{4}$ & $11.3 \pm 0.7 / 900 \pm 37$ & 0.568 \\
\hline TGL-13 & 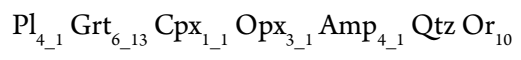 & $11.4 \pm 0.7 / 887 \pm 36$ & 0.562 \\
\hline TGL-13 & $\mathrm{Pl}_{7 \__{1}} \mathrm{Grt}_{10_{-} 5} \mathrm{Cpx}_{1_{-2} 2} \mathrm{Opx}_{5_{-3} 3} \mathrm{Amp}_{4_{-3} 3} \mathrm{Qtz} \mathrm{Or}_{4}$ & $11.6 \pm 0.7 / 889 \pm 36$ & 0.640 \\
\hline TGL-32 & $\mathrm{Pl}_{14} \mathrm{Grt}_{8_{-} 8} \mathrm{Cpx}_{8} \mathrm{Opx}_{18} \mathrm{Qtz}$ & $14.7 \pm 1.3 / 1,199 \pm 99$ & 0.893 \\
\hline TGL-32 & $\mathrm{Pl}_{15} \mathrm{Grt}_{1 \_17} \mathrm{Cpx}_{10} \mathrm{Opx}_{5} \mathrm{Qtz}$ & $13.8 \pm 1.6 / 1,108 \pm 121$ & 0.923 \\
\hline TGL-32 & $\mathrm{Pl}_{8} \mathrm{Grt}_{4-13} \mathrm{Cpx}_{13} \mathrm{Opx}_{16} \mathrm{Qtz}$ & $13.8 \pm 1.5 / 1,123 \pm 118$ & 0.915 \\
\hline TGL-32 & $\mathrm{Pl}_{14} \mathrm{Grt}_{8 \_8} \mathrm{Cpx}_{8} \mathrm{Opx}_{18} \mathrm{Qtz} \mathrm{Or}_{1}$ & $13.2 \pm 1.6 / 1,039 \pm 116$ & 0.914 \\
\hline TGL-32 & $\mathrm{Pl}_{15} \mathrm{Grt}_{1 \_17} \mathrm{Cpx}_{10} \mathrm{Opx}_{5} \mathrm{Qtz} \mathrm{Or}_{9}$ & $14.6 \pm 1.6 / 1,124 \pm 114$ & 0.912 \\
\hline TGL-32 & $\mathrm{Pl}_{8} \mathrm{Grt}_{4 \_13} \mathrm{Cpx}_{13} \mathrm{Opx}_{16} \mathrm{Qtz} \mathrm{Or}_{1}$ & $12.7 \pm 1.3 / 988 \pm 98$ & 0.910 \\
\hline TGL-58 & $\mathrm{Pl}_{4} \mathrm{Grt}_{11-4} \mathrm{Cpx}_{23} \mathrm{Opx}_{21} \mathrm{Amp}_{1} \mathrm{Bt}_{4} \mathrm{Qtz}$ & $12.0 \pm 0.9 / 958 \pm 38$ & 0.623 \\
\hline TGL-58 & $\mathrm{Pl}_{2} \mathrm{Grt}_{11 \_13} \mathrm{Cpx}_{22} \mathrm{Opx}_{25} \mathrm{Amp}_{3} \mathrm{Bt}_{3} \mathrm{Qtz}$ & $12.3 \pm 0.6 / 928 \pm 28$ & 0.631 \\
\hline TGL-58 & $\mathrm{Pl}_{1} \mathrm{Grt}_{8 \_3} \mathrm{Cpx}_{13} \mathrm{Opx}_{17} \mathrm{Amp}_{4} \mathrm{Bt}_{5} \mathrm{Qtz}$ & $12.7 \pm 1.0 / 979 \pm 43$ & 0.468 \\
\hline TGL-58 & $\mathrm{Pl}_{4} \mathrm{Grt}_{11 \_} \mathrm{Cpx}_{23} \mathrm{Opx}_{21} \mathrm{Amp}_{1} \mathrm{Bt}_{4} \mathrm{Qtz} \mathrm{Or}_{1}$ & $11.4 \pm 0.9 / 906 \pm 39$ & 0.632 \\
\hline TGL-58 & $\mathrm{Pl}_{2} \mathrm{Grt}_{11 \_13} \mathrm{Cpx}_{22} \mathrm{Opx}_{25} \mathrm{Amp}_{3} \mathrm{Bt}_{3} \mathrm{Qtz} \mathrm{Or}_{2}$ & $10.9 \pm 1.0 / 910 \pm 43$ & 0.656 \\
\hline TGL-58 & $\mathrm{Pl}_{1} \mathrm{Grt}_{8 \_3} \mathrm{Cpx}_{13} \mathrm{Opx}_{17} \mathrm{Amp}_{4} \mathrm{Bt}_{5} \mathrm{Qtz}_{\mathrm{Or}}$ & $10.91 \pm 0.9 / 915 \pm 41$ & 0.656 \\
\hline MAG-11 & $\mathrm{Pl}_{20} \mathrm{Grt}_{5 \_} \mathrm{Cpx}_{22} \mathrm{Opx}_{19} \mathrm{Amp}_{26}$ & $12.8 \pm 0.9 / 929 \pm 29$ & 0.350 \\
\hline MAG-11 & $\mathrm{Pl}_{18} \mathrm{Grt}_{5-7} \mathrm{Cpx}_{22} \mathrm{Opx}_{13} \mathrm{Amp}_{35}$ & $13.0 \pm 0.8 / 955 \pm 27$ & 0.354 \\
\hline MAG-11 & $\mathrm{Pl}_{21} \mathrm{Grt}_{3 \_8} \mathrm{Cpx}_{30} \mathrm{Opx}_{14} \mathrm{Amp}_{29}$ & $12.9 \pm 0.7 / 948 \pm 34$ & 0.359 \\
\hline
\end{tabular}

Samples: i) garnet granulitic gneiss: TGL-13: amp-cpx-grt granulitic gneiss; TGL-32: grt-cpx granulitic gneiss; TGL-58: cpx-grt granulitic gneiss with bt, amp and rt; ii) basic granulite: MAG-11: cpx-amp basic granulite with grt. The numbers subscribed to the minerals indicate the mineral chemical analysis point used in the geothermobarometric calculations (See Supplementary Tables). 

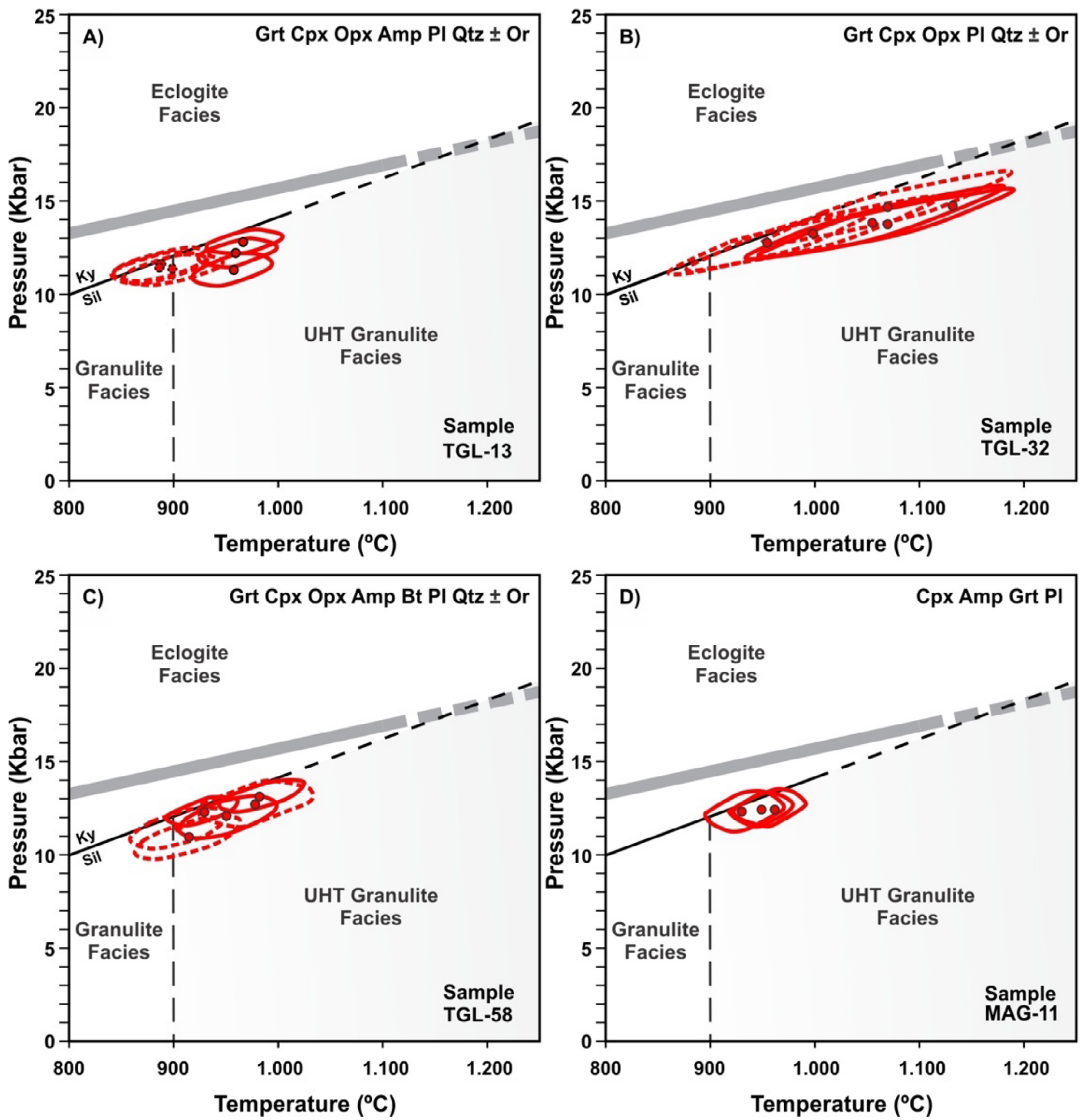

Figure 9. $P$ - $T$ diagrams showing pressure and temperature conditions calculated by THERMOCALC software (average $P$ - $T$ ) from Guaxupé Complex samples. (A) Sample TGL-13; (B) sample TGL-32; (C) sample TGL-58; (D) sample MAG-11. The continuous lines represent orthoclase-free calculations. The dashed lines represent the $P-T$ calculations performed with orthoclase-bearing mineral assemblage. Metamorphic facies diagram modified from Spear (1993) and Harley (2016).

between $10.90 \pm 1.0$ to $11.40 \pm 0.90 \mathrm{kbar}$ and $906 \pm 39$ to 915 $\pm 41^{\circ} \mathrm{C}$, with correlations in the order of 0.6 (Fig. 9C, Tab. 1).

For basic granulite with garnet (sample MAG-11), the mineral assemblage considered was sahlite + hypersthene + Mg-hastingsite + labradorite + almandine. Pressure and temperature values range from $12.8 \pm 0.90$ to $13.0 \pm 0.8 \mathrm{kbar}$ and from $929 \pm 29$ to $955 \pm 27^{\circ} \mathrm{C}$, with correlations of 0.35 (Fig. 9D, Tab. 1).

\section{RCLC (thermobarometry corrected for retrograde exchange)}

Garnet and orthopyroxene core compositions of garnet granulitic gneisses (samples TGL-13, TGL-32, and TGL-58) and basic granulite (sample MAG-11) were used to calculate pressure and temperature conditions using the RCLC program by Pattison et al. (2003). The program is based on $\mathrm{Al}$-solubility in orthopyroxene in equilibrium with garnet, correcting effects of late Fe-Mg exchange. The results and the mineral assemblage used in the calculations are presented in Table 2 and Figure 10.

Temperature and pressure estimates vary between each sample of garnet granulitic gneiss. For sample TGL-13, P-T conditions range from 922 to $936^{\circ} \mathrm{C}$ and from 12.54 to $12.72 \mathrm{kbar}$, with an average of $927 \pm 8^{\circ} \mathrm{C}$ and $12.62 \pm 0.10 \mathrm{kbar}$ (Fig. 10A, Tab. 2). For sample TGL-32, temperature and pressure conditions range from 927 to $948^{\circ} \mathrm{C}$ and from 12.56 to $12.97 \mathrm{kbar}$, 
Table 2. $P-T$ results calculated using Pattison et al. (2003) (RCLC software).

\begin{tabular}{|c|c|c|c|c|}
\hline Sample & Mineral Assemblage & $\begin{array}{l}\mathbf{X}_{\mathrm{Al}} \\
\mathbf{O p x}\end{array}$ & $\begin{array}{c}\mathbf{T} \\
\left({ }^{\circ} \mathbf{C}\right)\end{array}$ & $\begin{array}{c}\mathbf{P} \\
(\text { Kbar })\end{array}$ \\
\hline TGL-13 & $\mathrm{Grt}_{8_{-} 14} \mathrm{Opx}_{3_{-3} 3} \mathrm{Pl}_{4_{-} 6} \mathrm{Qtz}$ & 0.03 & 936 & 12.72 \\
\hline TGL-13 & $\mathrm{Grt}_{6 \_13} \mathrm{Opx}_{3_{-1} 1} \mathrm{Pl}_{4 \_1} \mathrm{Qtz}$ & 0.028 & 924 & 12.54 \\
\hline TGL-13 & $\mathrm{Grt}_{10 \_5} \mathrm{Opx}_{5_{-3} 3} \mathrm{Pl}_{7_{-1} 1} \mathrm{Qtz}$ & 0.028 & 922 & 12.6 \\
\hline Average & & & 927 & 12.62 \\
\hline \multicolumn{2}{|c|}{ Standard deviation } & & 8 & 0.1 \\
\hline TGL-32 & $\mathrm{Grt}_{8_{-8}} \mathrm{Opx}_{18} \mathrm{Pl}_{14} \mathrm{Qtz}$ & 0.03 & 948 & 12.56 \\
\hline TGL-32 & $\mathrm{Grt}_{1 \_17} \mathrm{Opx}_{5} \mathrm{Pl}_{15} \mathrm{Qtz}$ & 0.032 & 936 & 12.86 \\
\hline TGL-32 & $\mathrm{Grt}_{4 \_13} \mathrm{Opx}_{16} \mathrm{Pl}_{8} \mathrm{Qtz}$ & 0.032 & 927 & 12.97 \\
\hline Average & & & 937 & 12.80 \\
\hline \multicolumn{2}{|c|}{ Standard deviation } & & 11 & 0.21 \\
\hline TGL-58 & $\mathrm{Grt}_{11 \_4} \mathrm{Opx}_{21} \mathrm{Pl}_{4} \mathrm{Bt}_{4} \mathrm{Qtz}$ & 0.035 & 1,079 & 14.97 \\
\hline TGL-58 & $\mathrm{Grt}_{11 \_13} \underset{\mathrm{Qtz}}{\mathrm{Opx}_{25} \mathrm{Pl}_{2} \mathrm{Bt}_{3}}$ & 0.034 & 1,069 & 14.71 \\
\hline TGL-58 & $\mathrm{Grt}_{8 \_3} \mathrm{Opx}_{17} \mathrm{Pl}_{1} \mathrm{Bt}_{5} \mathrm{Qtz}$ & 0.035 & 1,085 & 14.83 \\
\hline Average & & & 1,078 & 14.84 \\
\hline \multicolumn{2}{|c|}{ Standard deviation } & & 8 & 0.13 \\
\hline MAG-11 & $\mathrm{Grt}_{5-6} \mathrm{Opx}_{19} \mathrm{Pl}_{20}$ & 0.044 & 1,005 & 13.51 \\
\hline MAG-11 & $\mathrm{Grt}_{5-7} \mathrm{Opx}_{13} \mathrm{Pl}_{18}$ & 0.039 & 967 & 12.63 \\
\hline MAG-11 & $\mathrm{Grt}_{3 \_8} \mathrm{Opx}_{14} \mathrm{Pl}_{21}$ & 0.038 & 927 & 12.68 \\
\hline Average & & & 966 & 12.94 \\
\hline Standard & eviation & & 39 & 0.49 \\
\hline
\end{tabular}

$\mathrm{T}\left({ }^{\circ} \mathrm{C}\right)$ and $\mathrm{P}(\mathrm{Kbar})$ : temperature and pressure estimated using Pattison et al. (2003) (RCLC software), based on $\mathrm{Al} / 2$ mode; $\mathrm{X}_{\mathrm{Al}} \mathrm{Opx}$ : proportion of Al filling the octahedral site. The numbers subscribed to the minerals indicate the mineral chemical analysis point used in the geothermobarometric calculations (See Supplementary Tables).

with an average of $937 \pm 11^{\circ} \mathrm{C}$ and $12.81 \pm 0.21 \mathrm{kbar}$ (Fig. 10B, Tab. 2). For sample TGL-58, temperature ranges from 1,069 to $1,085^{\circ} \mathrm{C}$ and pressure between $14.71-14.97 \mathrm{kbar}$, with an average conditions of $1,078 \pm 8^{\circ} \mathrm{C}$ and $14.84 \pm 0.13 \mathrm{kbar}$ (Fig. 10C, Tab. 2). The P-T conditions calculated for basic granulite (sample MAG-11) range from 927 to $1,005^{\circ} \mathrm{C}$ and from 12.63 to $13.51 \mathrm{kbar}$, with an average of $966 \pm 39^{\circ} \mathrm{C}$ and $12.94 \pm 0.49$ kbar (Fig. 10D, Tab. 2).

\section{Zr-in-rutile thermometry}

Zr-in-rutile temperatures were calculated using the Tomkins et al. (2007) calibration. Only one garnet granulitic gneiss sample (sample TGL-58) has the appropriate buffering assemblage (zircon, quartz, and rutile) to apply this method. The pressure conditions were fixed in $14.0 \mathrm{kbar}$ (obtained based on Al-solubility thermobarometry, by Pattison et al. 2003).

$\mathrm{Zr}$ concentrations in matrix rutile crystals range from 1,235 to $3,405 \mathrm{ppm}$ and correspond to temperatures of $799 \pm 6$ to $919 \pm 4^{\circ} \mathrm{C}$ at $14 \mathrm{kbar}$ (Tab. 3, Fig. 11). $\mathrm{Zr}$ concentrations in rutile inclusions in garnet range from 2,470 to $7,078 \mathrm{ppm}$, and correspond to temperatures of $878 \pm 4$ to $1,024 \pm 2^{\circ} \mathrm{C}$ at 14 kbar (Tab. 3, Fig. 11).

\section{DISCUSSION}

\section{Metamorphism and $P-T$ path}

The pressure and temperature values obtained for the Basal Granulite Unit of the Guaxupé Complex northern portion indicate metamorphic peak around $1,078^{\circ} \mathrm{C}$ and $14.8 \mathrm{kbar}$, based on orthopyroxene $\mathrm{Al}$-solubility in equilibrium with garnet in garnet granulitic gneiss (sample TGL-58 - grt + opx + $\mathrm{cpx}+\mathrm{rt}$ ). Calculations with the RCLC software show greater homogeneity in $P$ - $T$ values in comparison to THERMOCALC results, even though the calculated conditions for both are similar. In the case of sample TGL-32, with grt + cpx + opx $+\mathrm{pl}+\mathrm{qtz}$ mineral assemblage, the temperature values above $1,150^{\circ} \mathrm{C}$ and with high standard deviation were interpreted as overestimated and unreliable.

The main metamorphic re-equilibration is recorded by P-T conditions of ca. 930 to $800^{\circ} \mathrm{C}$ and 13.5 to $11.0 \mathrm{kbar}$, marked mainly by the formation of amphibole and biotite in ortho-derived rocks. Considering orthoclase in geothermobarometric calculations in garnet granulitic gneisses, pressure and temperature conditions tend to be lower, suggesting that the potassium feldspar formation is associated with anatexis process by decompression, but still in the granulite facies (above orthoclase isograd).

Zirconium concentrations in rutile are highly dispersed, which is common under granulite and ultra-high temperature conditions (Luvizotto and Zack 2009, Jiao et al. 2011, Meyer et al.2011, Kooijman et al.2012, Taylor-Jones and Powell 2015, Harley 2016, Pape et al. 2016, Hart et al. 2018). Matrix rutile crystals show lower $\mathrm{Zr}$ concentrations (1,235 to 3,405 ppm) in comparison to rutile inclusions concentrations $(2,470$ to $7,078 \mathrm{ppm}$ ) in garnet.

Low $\mathrm{Zr}$ values in the matrix correspond to lower temperature conditions ( 799 to $918^{\circ} \mathrm{C}$ ). $\mathrm{Zr}$ concentrations in rutile inclusions in garnet correspond to temperatures ranging from 878 to $1,024^{\circ} \mathrm{C}$, which are lower than the metamorphic peak temperatures calculated by the RCLC and THERMOCALC softwares, but still in agreement with those of UHT metamorphism. The lower temperatures obtained in matrix crystals may occur due to the effect of post-peak metamorphic re-equilibration processes, such as decompression and cooling, which mobilize elements such as $\mathrm{Zr}$, resulting in a variable retrograde adjustment of rutile $\mathrm{Zr}$ concentrations (Jiao et al. 2011, Hart et al.2018). At UHT granulite-facies conditions, host minerals with low Zr-diffusivity (e.g., garnet or pyronexe) can shield rutile inclusions from re-equilibration during post-peak processes (Zack et al. 2004, Kooijman et al. 2012, Pauly et al. 2016), corresponding to temperatures closer to the metamorphic peak.

Garnet, biotite, and amphibole chemical characteristics corroborate with high-grade metamorphism conditions. Garnet composition is dominated by end-members almandine and pyrope. The compositional profiles are almost flat, with small variations toward the rims. In high-grade metamorphism, there often is a reduction of compositional zoning, representing the homogenization of the composition, followed by little modification during cooling, marked by the small variations toward the rims (Tracy et al. 1976, Woodsworth 1977, Yardley 

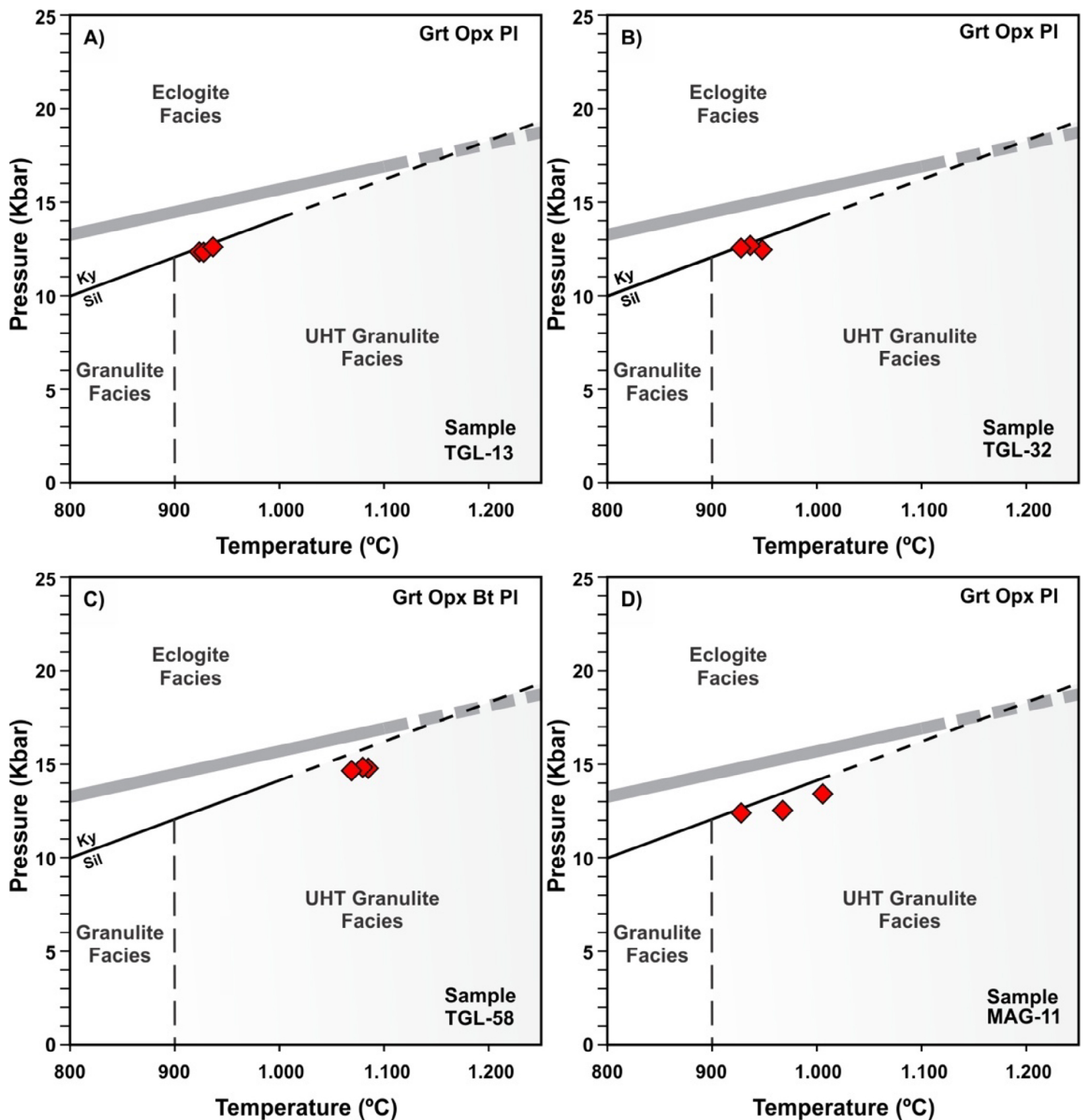

Figure 10. $P-T$ diagram showing pressure and temperature conditions calculated by RCLC software from Guaxupé Complex samples. (A) Sample TGL-13; (B) sample TGL-32; (C) sample TGL-58; (D) sample MAG-11. Metamorphic facies diagram modified from Spear (1993) and Harley (2016).

1977, Spear 1993, Carlson and Schwarze 1997, Cooke et al. 2000). The high $\mathrm{X}_{\mathrm{Mg}}, \mathrm{Al}^{\mathrm{IV}}$, and Ti contents in biotite composition indicate typical characteristics of high metamorphic grade (Guidotti 1984), as well as the relatively high concentrations of $\mathrm{Na}_{\mathrm{A}}, \mathrm{K}_{\mathrm{A}}, \mathrm{Al}^{\mathrm{IV}}, \mathrm{Al}^{\mathrm{VI}}$, and $\mathrm{Ti}$ in amphibole composition, which also suggest higher grade conditions (Kostyuk and Sobolev 1969, Robinson et al. 1982, Deer et al. 1997a).

The higher pressure conditions obtained are at equilibrium in the sillimanite stability field and are in coherence with the mineralogical aspects and the geological setting. The mineral assemblage ( $g r t+o p x+c p x+r t)$ at equilibrium, the high pyrope concentrations in garnet, and the relatively high $\mathrm{Al}$ content in clinopyroxene and orthopyroxene in ortho-derived rocks (Deer et al. 1997c, Pattison et al. 2003) prove that these studied rocks experienced high pressures.
The pressure and temperature conditions calculated in this contribution (ca. $1,078^{\circ} \mathrm{C}$ and $14.8 \mathrm{kbar}$ ) are interpreted as close to the metamorphic peak in the basal portion of the Guaxupé Complex and are in agreement with ultra-high temperature metamorphic conditions. The $P-T$ peak and re-equilibration conditions are congruent with the maximum and minimal temperatures and pressures previously calculated for the basal granulite unit of Guaxupé Complex $\left(850^{\circ} \mathrm{C}\right.$ and $8.5 \mathrm{kbar}$ - Iyer et al. 1996; $900^{\circ} \mathrm{C}$ and $12.5 \mathrm{kbar}$ - Campos Neto and Caby $1999 ; 1,040^{\circ} \mathrm{C}$ and $14.4 \mathrm{kbar}$ - Del Lama et al. 2000; $890^{\circ} \mathrm{C}$ and $11 \mathrm{kbar}$ - Garcia and Campos Neto $2003 ; 900^{\circ} \mathrm{C}$ and $10 \mathrm{kbar}$ - Nascimento and Oliveira $2012 ; 900^{\circ} \mathrm{C}$ and 12 $\mathrm{kbar}$ - Rocha et al. 2018; $998 \pm 23^{\circ} \mathrm{C}$ - Tedeschi et al. 2018).

Mineralogical, petrographic, chemical, and geothermobarometric data indicate metamorphic re-equilibration in the 
Table 3. Trace element composition (in ppm) of the analyzed rutile from cpx-grt granulitic gneiss with bt, amp, and rt (sample TGL-58).

\begin{tabular}{|c|c|c|c|c|c|c|}
\hline \multicolumn{2}{|c|}{$\begin{array}{l}\text { Detection } \\
\text { Limit (in ppm): }\end{array}$} & \multirow{2}{*}{$\begin{array}{c}30 \\
\mathrm{Si}\end{array}$} & \multirow{2}{*}{$\begin{array}{l}45 \\
\mathrm{Zr}\end{array}$} & \multicolumn{2}{|c|}{$\begin{array}{c}\text { Tomkins et al. } \\
\quad(2007)\end{array}$} & \multirow{2}{*}{$\begin{array}{c}\begin{array}{c}\text { Errors } \\
(2 \sigma)\end{array} \\
\begin{array}{c}\mathbf{T} \\
\left({ }^{\circ} \mathbf{C}\right)\end{array}\end{array}$} \\
\hline Texture & Analysis & & & $\begin{array}{c}\mathbf{P} \\
(\text { Kbar })\end{array}$ & $\begin{array}{c}\mathbf{T} \\
\left({ }^{\circ} \mathbf{C}\right)\end{array}$ & \\
\hline matrix & rt_2 & $\mathrm{BD}$ & 1,235 & 14 & 799 & \pm 6 \\
\hline inclusion & rt_3 & 293 & 2,500 & 14 & 880 & \pm 4 \\
\hline matrix & rt_5 & 66 & 2,575 & 14 & 884 & \pm 4 \\
\hline matrix & rt_6 & 179 & 2,765 & 14 & 893 & \pm 4 \\
\hline inclusion & rt_7 & 103 & 2,797 & 14 & 894 & \pm 4 \\
\hline inclusion & rt_9 & 83 & 2,881 & 14 & 898 & \pm 4 \\
\hline inclusion & rt_10 & 49 & 3,324 & 14 & 916 & \pm 4 \\
\hline inclusion & rt_11 & 84 & 3,409 & 14 & 920 & \pm 4 \\
\hline matrix & rt_12 & $\mathrm{BD}$ & 3,352 & 14 & 917 & \pm 4 \\
\hline matrix & rt_13 & $\mathrm{BD}$ & 2,744 & 14 & 892 & \pm 4 \\
\hline inclusion & rt_14 & 70 & 3,109 & 14 & 907 & \pm 4 \\
\hline matrix & rt_16 & $\mathrm{BD}$ & 2,654 & 14 & 887 & \pm 4 \\
\hline inclusion & rt_17 & 130 & 4,072 & 14 & 943 & \pm 4 \\
\hline inclusion & rt_18 & 122 & 7,078 & 14 & 1,024 & \pm 2 \\
\hline matrix & rt_19 & 38 & 3,372 & 14 & 918 & \pm 4 \\
\hline matrix & rt_21 & 70 & 3,100 & 14 & 907 & \pm 4 \\
\hline matrix & rt_22 & 36 & 3,180 & 14 & 910 & \pm 4 \\
\hline inclusion & rt_23 & 125 & 3,156 & 14 & 909 & \pm 4 \\
\hline matrix & rt_25 & 35 & 3,226 & 14 & 912 & \pm 4 \\
\hline matrix & rt_26 & $\mathrm{BD}$ & 1,945 & 14 & 850 & \pm 4 \\
\hline matrix & rt_27 & 99 & 3,137 & 14 & 909 & \pm 4 \\
\hline inclusion & rt_28 & 230 & 2,470 & 14 & 878 & \pm 4 \\
\hline matrix & rt_29 & $\mathrm{BD}$ & 3,405 & 14 & 919 & \pm 4 \\
\hline inclusion & rt_30 & 129 & 3,205 & 14 & 911 & \pm 4 \\
\hline inclusion & rt_31 & 49 & 3,217 & 14 & 912 & \pm 4 \\
\hline inclusion & rt_32 & 39 & 2,755 & 14 & 892 & \pm 4 \\
\hline
\end{tabular}

P (Kbar): Pressure estimated based on RCLC calculations; T $\left({ }^{\circ} \mathrm{C}\right)$ : temperature calculated using Tomkins et al. (2007) calibration ( $\alpha$-quartz field); BD: below detection limit.

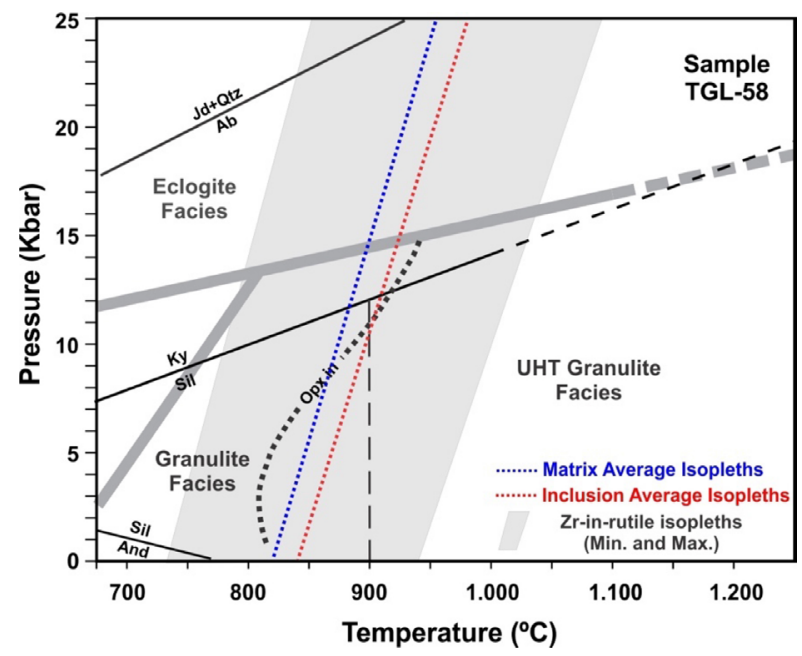

Figure 11. $P-T$ diagram showing the minimum, average and maximum isopleths of Zr-in-rutile from sample TGL-58 using the calibration of Tomkins et al. (2007). sillimanite stability field, mainly due to a decrease in pressure, followed by a slower decrease in temperature (near-isothermal decompression), following the kyanite-sillimanite stability limit line. These results suggest a clockwise P-T path (Fig. 12), as also proposed by Zanardo (1992), Iyer et al. (1996), Del Lama et al. (2000), Nascimento and Oliveira (2012), and Rocha et al. (2018).

\section{Tectono-metamorphic implications}

The pressure and temperature conditions associated with the lithological, petrographic, and mineral chemistry data described in this contribution corroborate a regional framework of juxtaposed crustal blocks marked by a suture zone (Davino 1979, Almeida et al. 1980, Haralyi and Hasui 1982, Haralyi et al. 1985, Zanardo 1992, Malagutti Filho et al. 1996, Ebert and Hasui 1998, Dardenne 2000, Zanardo et al. 2006, Hasui 2010).

The geological setting of the region results from a Neoproterozoic continental collision and corresponds to the obduction of granulitic terranes represented by the Guaxupé Complex (Paranapanema Block) over an indentor (edge of the São Francisco Craton) (Brito Neves et al. 1999, 2014, Dardenne 2000, Alkmim et al. 2001, Cordani et al. 2003, Fuck et al. 2017, Valeriano 2017). The blocks' boundaries are defined by wide gravimetric discontinuities (Bouguer anomalies involving type A subduction) (Davino 1979, Almeida et al. 1980, Haralyi and Hasui 1982, Haralyi et al. 1985, Malagutti Filho et al. 1996).

The results described in this contribution are in agreement with geological literature data and indicate that Guaxupé Complex terranes, represented by a lower crust segment, thrusted over the São Francisco Craton, initially, in a frontal ramp with direction close to NS to NW-SE. In the progression of the collision, the rotation of tensors responsible for the deformation takes place, leading the suture zone to develop lateral/oblique ramp features toward E-W and sinistral movement (Morales 1988, 1993, Zanardo 1992). The structural data are congruent with this setting, showing dominant foliation with NW to WNW direction tending to E-W and increasingly

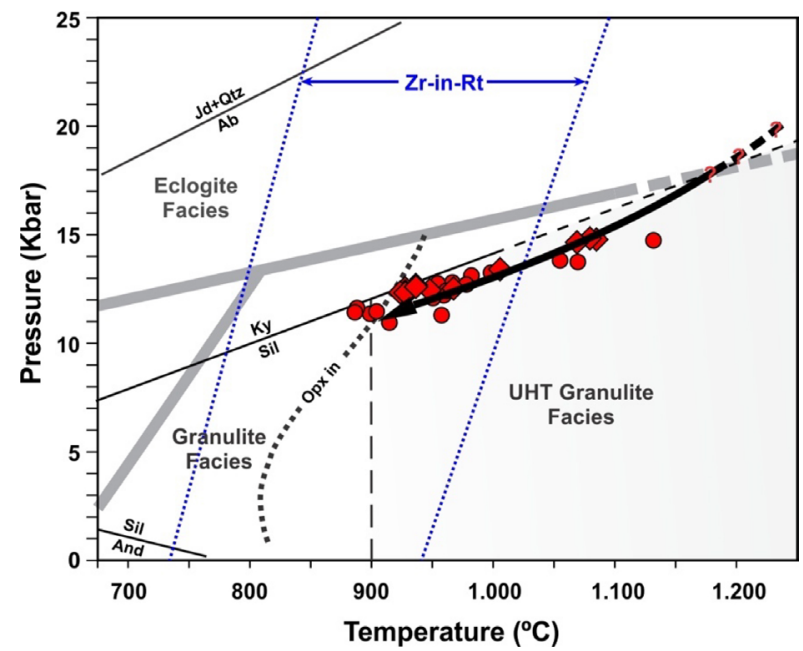

Figure 12. $P-T$ diagram showing pressure and temperature conditions calculated in this contribution and $P-T$ path from samples of the basal portion of Guaxupé Complex. Metamorphic facies diagram modified from Spear (1993) and Harley (2016). 
steep dips to the north direction of the unit. The mineral and stretching lineations exhibit NW direction and dip toward SE. Superposition or rotation of the lineation to E-W to ENE direction are described in the VSZ (Zanardo 1992, Morales 1993).

The pressure and temperature conditions interpreted as close to the metamorphic peak are related to the development stage of the frontal ramp (continental collision). The transpressional movement of the oblique/lateral ramp (VSZ) allowed the uplift of deepest portions of the lower crust in the northern Guaxupé Complex domain (Del Lama 1998, Del Lama et al. 2000, Zanardo et al. 2006). This segment is interpreted to record the higher pressure and temperature conditions of the granulitic terrane and agrees with the ultra-high temperature and high-pressure conditions obtained in this paper.

The progression of deformation resulted in the metamorphic re-equilibration under conditions around 930 to $800^{\circ} \mathrm{C}$ and 13.5 to $11.0 \mathrm{kbar}$ in granulite facies in the sillimanite stability field. The results indicate faster decrease in pressure than in temperature, suggesting a near-isothermal decompression and a clockwise $P-T$ path.

$\mathrm{U}-\mathrm{Pb}$ zircon geochronological data indicate ages between 625 and $600 \mathrm{Ma}$ for the syn-collisional metamorphism of the SGN (Mora et al. 2014, Vinagre et al. 2014, Rocha et al. 2018), consistent with ages between 630 and $600 \mathrm{Ma}$ for the Southern Brasília Orogen collision (Basei et al. 1995, Janasi 1999, Campos Neto and Caby 2000, Vlach and Gualda 2000, Trouw et al. 2000, 2013, Campos Neto et al. 2004, 2011, Coelho et al. 2017, Tedeschi et al. 2018).

The geotectonic model and metamorphic trajectory suggested in this contribution are analogous to the large hot orogens model of Jamieson and Beaumont $(2011,2013)$ and Harley (2016). In this model, the deeper units compatible with ultra-high temperature conditions are lifted as nappes by ductile thrusting during syn-convergence thickening. The arrival of an indentor leads to upward ramping, forcing the expulsion of lower crustal segment rocks. Lower crustal rocks forced upward experiencing some decompression with cooling, and suggest a clockwise $P-T$ path.

\section{CONCLUSIONS}

The pressure and temperature conditions calculated for the basal portion of the Guaxupé Complex indicate metamorphic peak around $1,078^{\circ} \mathrm{C}$ and $14.8 \mathrm{kbar}$, compatible with ultra-high temperature metamorphism, marked by mineral assemblages composed of grt $+\mathrm{cpx}+\mathrm{opx}+\mathrm{pl} \pm \mathrm{qtz} \pm \mathrm{rt}$. This metamorphic stage was followed by re-equilibration in the sillimanite stability field of granulite facies at temperatures of 930 to $800^{\circ} \mathrm{C}$ and pressures of 13.5 to $11.0 \mathrm{kbar}$, following the boundary between the kyanite-sillimanite stability field.

Mineralogical, petrographic, mineral chemistry, and geotermobarometric data indicate that temperature and pressure conditions increase in NE direction of the Guaxupé Complex, close to the VSZ inflection to SE. The VSZ inflection (transpression segment) allowed the uplift of deeper portions of the granulitic sequence, recording higher pressure and temperature conditions.

The results presented in this contribution suggest a clockwise $P-T$ path, typical of crustal thickening zones (continental collision), followed by near-isothermal decompression during tectonic exhumation.

\section{ACKNOWLEDGMENTS}

T. G. Leme acknowledges Coordenação de Aperfeiçoamento de Pessoal de Nivel Superior, Brazil (CAPES) — Finance Code $001-$ (MSc scholarship). The authors are grateful to Renata A. S. Paes for her participation and help in fieldwork. We would like to thank Professor Marcos Aurelio F. de Oliveira for his comments and discussions. We also thank the two anonymous reviewers for their constructive comments that benefited and improved this manuscript.

\section{ARTICLE INFORMATION}

Manuscript ID: 20200005. Received on: 01/28/2020. Approved on: 07/30/2020.

T.G.L. wrote the first draft of the manuscript, prepared Figures 4, 5, 6, 7, 8, 9, and 10, and prepared all tables; G.R.B.N. revised and improved the manuscript and prepared Figures 1, 2, 3, 11, and 12; A.Z: revised and improved the manuscript.

Competing interests: The authors declare no competing interests.

\section{REFERENCES}

Alkmim F.F., Marshak S., Fonseca M.A. 2001. Assembling West Gondwana in the Neoproterozoic: clues from the São Francisco craton region, Brazil. Geology, 29(4):319-322. https://doi. org/10.1130/0091-7613(2001)029<0319:AWGITN>2.0.CO;2

Almeida F.F.M., Hasui Y., Davino A., Haralyi N.L.E. 1980. Informações geofísicas sobre o oeste mineiro e seu significado geotectônico. Anais da Academia Brasileira de Ciências, 52(1):49-60.

Basei M.A.S., Siga Jr. O., Sato K., Sproesser W.M. 1995. A metodologia Urânio- Chumbo na USP. Princípios metodológicos, aplicações e resultados obtidos. Anais da Academia Brasileira de Ciências, 67 (2):221-237.

Brito Neves B.B., Campos Neto M.C., Fuck R.A. 1999. From Rodinia to Western Gondwana: an approach to the Brasiliano-Pan African Cycle and orogenic collage. Episodes, 22(3):155-166. https://doi.org/10.18814/ epiiugs/1999/v22i3/002

Brito Neves B.B., Fuck R.A., Pimentel M.M. 2014. The Brasiliano collage in South America: a review. Brazilian Journal of Geology, 44(3):493-518. http://dx.doi.org/10.5327/Z2317-4889201400030010

Brown M. 2007. Metamorphic conditions in orogenic belts: a record of secular change. International Geology Review, 49(3):193-234. https://doi. org/10.2747/0020-6814.49.3.193

Campos Neto M.C., Basei M.A.S., Janasi V.A., Moraes R. 2011. Orogen migration and tectonic setting of the Andrelândia Nappe system: An Ediacaran western Gondwana collage, south of São Francisco craton. Journal of South American Earth Sciences, 32(4):393-406. https://doi.org/10.1016/j.jsames.2011.02.006 
Campos Neto M.C., Basei M.A.S., Vlach S.R.F., Caby R., Szabó G.A.J., Vasconcelos P. 2004. Migração de Orógenos e Superposição de Orogêneses: Um Esboço da Colagem Brasiliana no Sul do Cráton do São Francisco, SE -Brasil. Geologia USP. Série Científica, 4(1):13-40. https://doi.org/10.5327/ S1519-874x2004000100002

Campos Neto M.C., Caby R. 1999. Neoproterozoic High-Pressure Metamorphism and Tectonic Constraint from the Nappe System South of the São Francisco Craton, Southeast Brazil. Precambrian Research, 97(1-2):3-26. https://doi.org/10.1016/S0301-9268(99)00010-8

Campos Neto M.C., Caby R. 2000. Terrane Accretion and Upward Extrusion of High-Pressure Granulites in the Neoproterozoic Nappes of Southeast Brazil: Petrologic and Structural Constraints. Tectonics, 19(4):669-687. https://doi.org/10.1029/1999TC900065

Campos Neto M.C., Cioffi C.R., Moraes R., Motta R.G., Siga Jr. O., Basei M.A.S. 2010. Structural and metamorphic control on the exhumation of high-P granulites: The Carvalhos Klippe example, from the oriental Andrelândia Nappe System, Southern portion of the Brasília Orogen, Brazil. Precambrian Research, 180(3-4):125-142. https://doi.org/10.1016/j. precamres.2010.05.010

Campos Neto M.C., Figueiredo M.C.H. 1992. Orogênese Rio Doce. In Congresso Brasileiro de Geologia, 37., 1992, São Paulo. Boletim de Resumos Expandidos, v. 1, p. 276-277.

Carlson W., Schwarze E. 1997. Petrological significance of prograde homogenization of growth zoning in garnet: an example from the Llano Uplift. Journal of Metamorphic Geology, 15(5):631-644. https://doi. org/10.1111/j.1525-1314.1997.tb00640.x

Cavalcante J.C., Cunha H.C., Chieregati L.A., Kaefer L.Q., Rocha J.M., Daitx E.C., Coutinho M.G.N., Yamamoto K., Drumond J.B.V., Rosa D.B., Ramalho R. 1979. Projeto Sapucaí - Estados de São Paulo e Minas Gerais: Relatório Final de Geologia. Brasília: Departamento Nacional da Produção Mineral, 299 p.

Cioffi C.R., Campos Neto M.C., Möller A., Rocha B.C. 2016. Paleoproterozoic continental crust generation events at 2.15 and $2.08 \mathrm{Ga}$ in the basement of the southern Brasília Orogen, SE Brazil. Precambrian Research, 275:176-196. https://doi.org/10.1016/j.precamres.2016.01.007

Coelho M.B., Trouw R.A.J., Ganade C.E., Vinagre R., Mendes J.C., Sato K. 2017. Constraining timing and PT conditions of continental collision and late overprinting in the Southern Brasília Orogen (SE-Brazil): $\mathrm{U}-\mathrm{Pb}$ zircon ages and geothermobarometry of the Andrelândia Nappe System. Precambrian Research, 292:194-215. https://doi.org/10.1016/j. precamres.2017.02.001

Cooke R.A., O’Brien P.J., Carswell D.A. 2000. Garnet zoning and the identification of equilibrium mineral compositions in highpressure-temperature granulites from the Moldanubian Zone, Austria. Journal of Metamorphic Geology, 18(5):551-569. https://doi. org/10.1046/j.1525-1314.2000.00273.x

Cordani U.G., Brito Neves B.B., D’Agrella-Filho M.S. 2003. From Rodinia to Gondwana: a review of the available evidence from South America. Gondwana Research, 6(2):275-283. https://doi.org/10.1016/ S1342-937X(05)70976-X

Dardenne M.A. 2000. The Brasília Fold Belt. In: Cordani U.G., Milani E.J., Thomaz-Filho A., Campos D.A. (eds). Tectonic Evolution of South America. 31st International Geological Congress. Rio de Janeiro, p. 231-263.

Davino A. 1979. O baixo gravimétrico da região de Caldas Novas, GO. In: Simpósio Regional de Geologia, 2., 1979, Rio Claro. Atas... v. 1, p. 87-100.

Deer W.A., Howie R.A., Zussman J. 1992. An Introduction to the RockForming Minerals. $2^{\text {nd }}$ ed. London: Longman, $696 \mathrm{p}$

Deer W.A., Howie R.A., Zussman J. 1997a. Rock-forming minerals: Double-chain silicates. $2^{\text {nd }}$ ed. London: Geological Society Publishing House, 764 p. v. $2 \mathrm{~A}$

Deer W.A., Howie R.A., Zussman J. 1997b. Rock-forming minerals: Orthosilicates. $2^{\text {nd }}$ ed. London: Geological Society Publishing House, 918 p.

Deer W.A., Howie R.A., Zussman J. 1997c. Rock-forming minerals: Single-chain silicates. 2 ed. London: Geological Society Publishing House, 668 p. v. 2 A.

Deer W.A., Howie R.A., Zussman J. 2004. Rock-forming minerals: Framework silicates: silica minerals, feldspathoids and the zeolites. London: Geological Society Publishing House, 982 p. v. 4B.

Del Lama E.A. 1998. Terrenos granulíticos de Guaxupé: Evolução petrológica de um segmento da crosta inferior. PhD Thesis, Instituto de Geociências e
Ciências Exatas, Universidade Estadual Paulista "Júlio de Mesquita Filho", Rio Claro, $188 \mathrm{p}$.

Del Lama E.A., Oliveira M.A.F., Zanardo A. 1994. Geotermobarometria em rochas do Complexo Campos Gerais ao norte da Zona de Cisalhamento Varginha. Revista Brasileira de Geociências, 24(4):1-7.

Del Lama E.A., Zanardo A., Oliveira M.A.F., Morales N. 2000. Exhumation of high-pressure granulites of the Guaxupé Complex, southeastern Brazil. Geological Journal, 35(3-4):231-249. https://doi.org/10.1002/gj.859

Ebert H.D., Hasui Y. 1998. Transpressional tectonics and strain partitioning during oblique collision between three plates in the Precambrian of southeast Brazil. In: Holdsworth R.E., Strachan R.A., Dewey J.E. (eds.). Continental Transpressional and Transtensional Tectonics. London: Geological Society, Special Publications, 135, p. 231-252. https://doi.org/10.1144/ GSL.SP.1998.135.01.15

Fonseca M.J.G., Silva Z.C.G., Campos D. de A., Tosatto P. 1979. Carta geológica do Brasil ao milionésimo: Folhas Rio de Janeiro, Vitória e Iguape. Texto explicativo. Brasília: MME/DNPM, $240 \mathrm{p}$.

Fuck R.A., Pimentel M.M., Alvarenga C.J., Dantas E.L. 2017. The northern Brasília belt. In: Heilbron M., Cordani U.G., Alkmim, F.F. (eds). São Francisco Craton, Eastern Brazil - Tectonic Genealogy of a Miniature Continent, Regional Geology Reviews. Berlin, Heidelberg: Springer, p. 205-220.

Garcia M.G.M., Campos Neto M.C. 2003. Contrasting metamorphic conditions in the Neoproterozoic collision-related nappes south of Sao Francisco Craton, SE Brazil. Journal of South American Earth Sciences, 15(8):853-870. https://doi.org/10.1016/S0895-9811(02)00147-5

Guidotti C.V. 1984. Micas in metamorphic rocks. In: Bailey S.W. (ed.). Micas. Reviews in Mineralogy and Geochemistry. Washington, D.C.: Mineralogical Society of America, 13(1), p. 357-467.

Haralyi N.L.E., Hasui Y. 1982. The gravimetric information and the archeanproterozoic structural framework of eastern Brazil. Revista Brasileira de Geociências, 12(1-3):160-166.

Haralyi N.L.E., Hasui Y., Mioto J.A., Hanza V.M., Rodrigues C.R.V. 1985. Ensaio sobre a estruturação crustal do Estado de Minas Gerais com base na informação geofísica e geológica. In: Silva A.B., Rao A.B., Barbosa A.L.M., Dutra C.V., Rodrigues C.R.V., Ladeira E.A., Gierth E., Machado I.F., Buchi J., Sad J.H.G., Danni J.C.M., Mioto J.A., Érico J.C.D., Fuzikawa K., Baecker M.L., Haralyi N.L.E., Leonardos Jr. O.H., Mendonça Jr. T., Hamza V.M., Hasui Y. (Eds.). Contribuições à Geologia e à Petrologia. Belo Horizonte: SBG, p. 71-93.

Harley S.L. 1998. On the occurrence and characterization of ultrahightemperature crustal metamorphism. In: Treloar P.J., O’Brien P.J. (eds.). What drives metamorphism and metamorphic reactions? London: Geological Society, Special Publication, 138(1), p. 81-107. https://doi.org/10.1144/ GSL.SP.1996.138.01.06

Harley S.L. 2004. Extending our understanding of ultrahigh temperature crustal metamorphism. Journal of Mineralogical and Petrological Sciences, 99(4):140-158. https://doi.org/10.2465/jmps.99.140

Harley S.L. 2008. Refining the P-T records of UHT crustal metamorphism. Journal of Metamorphic Geology, 26(2):125-154. https://doi. org/10.1111/j.1525-1314.2008.00765.x

Harley S.L. 2016. A matter of time: the importance of the duration of UHT metamorphism. Journal of Mineralogical and Petrological Sciences, 111 (2):50-72. https://doi.org/10.2465/jmps.160128

Hart E., Storey C., Harley S.L., Fowler M. 2018. A window into the lower crust: Trace element systematics and the occurrence of inclusions/ intergrowths in granulite-facies rutile. Gondwana Research, 59:76-86. https://doi.org/10.1016/j.gr.2018.02.021

Hasui Y. 2010. A grande colisão pré-cambriana do sudeste brasileiro e a estruturação regional. Geociências, 29(2):141-169.

Heineck C.A., Vieira V.S., Drumond J.B.V., Leite C.A.L., Lacerda Filho V.J. Valente C.R., Souza J.D., Lopes R.C., Malouf R.F., Oliveira I.W.B., Oliveira C.C., Sachs L.L.B., Paes V.J.C., Junqueira Pa. A. 2004. Folha SE.23 - Belo Horizonte. In: Schobbenhaus C., Gonçalves J.H., Santos J.O.S., Abram M.B., Leão Neto R., Matos G.M.M., Vidotti R.M., Ramos M.A.B., Jesus J.D.A. de (eds.). Carta Geológica do Brasil ao Milionésimo, Sistema de Informações Geográficas. Programa Geologia do Brasil. Brasília: CPRM. CD-ROM. 
Holland T.J.B., Powell R. 2000. AX: A program to calculate activities of mineral end members from chemical analyses (usually determined by electron microprobe). Available at: <http://www.ccp14.ac.uk/ccp/webmirrors/crush/astaff/holland/ax.html>. Accessed on: Mar. 19, 2019.

Iyer S.S., Choudhuri A., Pattison D.R.M., De Paoli G.R. 1996. Petrology and geochemistry of the Neoproterozoic Guaxupé granulite facies terrain, southeastern Brazil. Precambrian Research, 77(1-2):23-40. https://doi. org/10.1016/0301-9268(95)00043-7

Jamieson R.A., Beaumont C. 2011. Coeval thrusting and extension during lower crustal ductile flow-implications for exhumation of high-grade metamorphic rocks. Journal of Metamorphic Geology, 29(1):33-51. https:// doi.org/10.1111/j.1525-1314.2010.00908.x

Jamieson R.A., Beaumont C. 2013. On the origin of orogens. Geological Society of America Bulletin, 125(11-12):1671-1702. https://doi. org/10.1130/B30855.1

Janasi V.A. 1999. Petrogênese de granitos crustais na Nappe de Empurrão Socorro Guaxupé (SP-MG): uma contribuição da geoquímica elemental e isotópica. $\mathrm{PhD}$ Thesis, Instituto de Geociências, Universidade de São Paulo, 248 p.

Jiao S., Guo J., Mao Q., Zhao R. 2011. Application of Zr-in-rutile thermometry: a case study from ultrahigh-temperature granulites of the Khondalite belt, North China Craton. Contributions to Mineralogy and Petrology, 162(2):379-393. https://doi.org/10.1007/s00410-010-0602-3

Kelsey D.E. 2008. On ultrahigh-temperature crustal metamorphism. Gondwana Research, 13(1):1-29. https://doi.org/10.1016/j.gr.2007.06.001

Kelsey D.E., Hand M. 2015. On ultrahigh temperature crustal metamorphism: phase equilibria, trace element thermometry, bulk composition, heat sources, timescales and tectonic settings. Geoscience Frontiers, 6(3):311-356. https://doi.org/10.1016/j.gsf.2014.09.006

Kooijman E., Smit M.A., Mezger K., Berndt J. 2012. Trace element systematics in granulite facies rutile: implication for $\mathrm{Zr}$ geothermometry and provenance studies. Journal of Metamorphic Geology, 30(4):397-412. https://doi.org/10.1111/j.1525-1314.2012.00972.x

Kostyuk E.A., Sobolev V.S. 1969. Paragenetic types of calciferous amphiboles of metamorphic rocks. Lithos, 2(1):67-81. https://doi. org/10.1016/S0024-4937(69)80006-X

Lacerda Filho J.V., Valente C.R., Bahia R.B.C., Lopes R.C., Romanini S.J., Oliveira I.W.B., Oliveira C.C., Sachs L.L.B., Silva V.A., Batista I.H. 2004. Folha SD.22 - Goiás. In: Schobbenhaus C., Gonçalves J.H., Santos J.O.S., Abram M.B., Leão Neto R., Matos G.M.M., Vidotti R.M., Ramos M.A.B., Jesus J.D.A. de (eds.). Carta Geológica do Brasil ao Milionésimo, Sistema de Informações Geográficas. Programa Geologia do Brasil. Brasília: CPRM. CD-ROM.

Leake B.E., Woolley A.R., Arps C.E.S., Birch W., Gilbert M.C., Hawthorne F.C., Grice J.D., Kato A., Kisch H., Krivovichev V., Linthout K., Laird J., Mandarino J.A., Maresch W., Nickel E., Rock N.M.S., Schumacher J.C., Smith D.C., Stephenson N.C.N, Ungaretti E.J.W., Youzhi G. 1997. Nomenclature of amphiboles: report of the subcommittee on amphiboles of the international mineralogical association, commission on new minerals and mineral names. The Canadian Mineralogist, 35(1):219-246.

Leite C.A.S., Perrotta M.M., Silva L.C., Silva M.A., Heineck C.A., Salvador E.D., Vieira V.S., Lopes R.C., Silva M.G.M., Drumond J B.V., Malouf R.F., Lacerda Filho J.V., Valente C.R., Gomes S.D., Sachs L.L.B., Oliveira I.W.B., Ramgrab G.E., Netto C., Junqueira P.A., Paes V.J. C. 2004. Folha SE.23 - Rio de Janeiro. In: Schobbenhaus C., Gonçalves J.H., Santos J.O.S., Abram M.B., Leão Neto R., Matos G.M.M., Vidotti R.M., Ramos M.A.B., Jesus J.D.A. de (eds.). Carta Geológica do Brasil ao Milionésimo. Programa Geologia do Brasil. Brasília: CPRM. CD-ROM.

Leme T.G. 2019. Geotermobarometria das rochas do Grupo Araxá e do Complexo Guaxupé na região de Guaxupé - Nova Resende, MG. Ms Dissertation, Instituto de Geociências e Ciências Exatas, Universidade Estadual Paulista "Júlio de Mesquita Filho", Rio Claro, 175 p.

Leme T.G., Navarro G.R.B., Zanardo A., Montibeller C.C. 2019. Petrografia, química mineral e geotermobarometria de retroeclogito no Grupo Araxá na região da Zona de Cisalhamento Varginha, sudoeste de Minas Gerais. Geociências, 38(2):297-313.

Luvizotto G.L., Zack T. 2009. Nb and Zr behaviour in rutile during highgrade metamorphism and retrogression: an example from the Ivrea-Verbano Zone. Chemical Geology, 261(3-4):303-317. https://doi.org/10.1016/j. chemgeo.2008.07.023
Luvizotto G.L., Zack T., Triebold S., Von Eynatten H. 2009. Rutile occurrence and trace element behavior in medium-grade metasedimentary rocks: Example from the Erzgebirge, Germany. Mineralogy and Petrology, 97(3-4):233-249. https://doi.org/10.1007/s00710-009-0092-z

Malagutti Filho W., Ebert H.D., Hasui Y., Haralyi N.L.E., Sturaro J.R. 1996. Gravimetria e compartimentação crustal do sul de Minas Gerais. Geociências, 15(1):199-217.

Mantovani M.S.M., Brito Neves B.B. 2005. The Paranapanema Lithospheric Block: Its Importance for Proterozoic (Rodinia, Gondwana) Supercontinent Theories. Gondwana Research, 8(3):303-315. https://doi.org/10.1016/ S1342-937X(05)71137-0

Mantovani M.S.M., Brito Neves B.B. 2009. The Paranapanema Lithospheric Block: its nature and role in the Accretion of Gondwana. In: Gaucher C., Sial A., Halverson G., Frimmel H. (eds.). Neoproterozoic-Cambrian Tectonics, Global Change and Evolution: A Focus on South Western Gondwana. Amsterdam: Elsevier, p. 257-272.

Meyer M., John T., Brandt S., Klemd R. 2011. Trace element composition of rutile and the application of Zr-in-rutile thermometry to UHT metamorphism (Epupa Complex, NWNamibia). Lithos, 126(3-4):388-401. https://doi.org/10.1016/j.lithos.2011.07.013

Mora C.A.S., Campos Neto M.C., Basei M.A.S. 2014. Syn-collisional lower continental crust anatexis in the Neoproterozoic Socorro-Guaxupé Nappe System, southern Brasília Orogen, Brazil: Constraints from zircon $\mathrm{U}-\mathrm{Pb}$ dating, $\mathrm{Sr}-\mathrm{Nd}-\mathrm{Hf}$ signatures and whole-rock geochemistry. Precambrian Research, 255(3):847-864. https://doi.org/10.1016/j. precamres.2014.10.017

Moraes R., Nicollet C., Barbosa J.S.F., Fuck R.A., Sampaio A.R. 2015. Applications and limitations of thermobarometry in migmatites and granulites using as an example rocks of the Araçuaí Orogen in southern Bahia, including a discussion on the tectonic meaning of the current results. Brazilian Journal of Geology, 45(4):517-539. https://doi. org/10.1590/2317-4889201520150026

Morales N. 1988. Evolução lito-estrutural das rochas pré-cambrianas da região de São João da Boa Vista. Ms Dissertation, Intituto de Geociências, Universidade de São Paulo, São Paulo, 157 p.

Morales N. 1993. Evolução tectônica do cinturão de cisalhamento Campo do Meio na sua porção ocidental. $\mathrm{PhD}$ Thesis, Instituto de Geociências e Ciências Exatas, Universidade Estadual Paulista "Júlio de Mesquita Filho", Rio Claro, 2 v.

Nascimento M.B. 2010. Evolução metamórfica PTt da porção norte do Complexo Guaxupé na região de Arceburgo-Santa Cruz da Prata, MG. $\mathrm{PhD}$ Thesis, Instituto de Geociências e Ciências Exatas, Universidade Estadual Paulista "Júlio de Mesquita Filho", Rio Claro, 141 p.

Nascimento M.B., Oliveira M.A.F. 2012. Geotermobarometria de Granulitos Associados à Supracrustais na Porção Norte do Complexo Guaxupé-Região de Arceburgo-Santa Cruz do Prata, MG. Geociências, 31(2):207-228.

Oliveira M.A.F., Negri F.D.A., Zanardo A., Morales N. 2019. Archean and paleoproterozoic crust generation events, Amparo complex and Serra Negra orthogneiss in southern Brasília Orogen, SE Brazil. Journal of South American Earth Sciences, 90:137-154. https://doi.org/10.1016/j.jsames.2018.11.029

Pape J., Mezger K., Robyr M. 2016. A systematic evaluation of the Zr-inrutile thermometer in ultra-high temperature (UHT) rocks. Contributions to Mineralogy and Petrology, 171(5):1-20. https://doi.org/10.1007/ s00410-016-1254-8

Pattison D.R.M., Chacko T., Farquhar J., McFarlane C.R.M. 2003. Temperatures of granulite-facies metamorphism: constraints from experimental phase equilibria and thermobarometry corrected for retrograde exchange. Journal of Petrology, 44(5):867-900. https://doi. org/10.1093/petrology/44.5.867

Pauly J., Marschall H.R., Meyer H.P., Chatterjee N., Monteleone B. 2016. Prolonged Ediacaran-Cambrian metamorphic history and short-lived high-pressure granulite facies metamorphism in the H.U. Sverdrupfjella, Dronning Maud Land (East Antarctica): evidence for continental collision during Gondwana assembly. Journal of Petrology, 57(1):185-228. https:// doi.org/10.1093/petrology/egw005

Powell R., Holland T.J.B. 1994. Optimal geothermometry and geobarometry. American Mineralogist, 79(1-2):120-133.

Richard L.R. 1995. Mineralogical and Petrological Data Processing System. MINPET for Windows. Version 2.02. Québec: MinPet Geological Software. 
Robinson P., Spear F.S., Schumacher J.C., Laird J., Klein C., Evans B.W., Doolan B.L. 1982. Phase relations of metamorphic amphiboles: Natural occurrence and theory. In: Veblen D.R., Ribbe P.H. (eds). Amphiboles: Petrology and Experimental Phase Relations. Reviews in Mineralogy and Geochemistry. Washington, D.C., Mineralogical Society of America, p. 1-227.

Rocha B.C., Moraes R., Möller A., Cioffi C.R. 2018. Magmatic inheritance vs. UHT metamorphism: Zircon petrochronology of granulites and petrogenesis of charnockitic leucosomes of the Socorro-Guaxupé nappe, SE Brazil. Lithos, 314-315:16-39. https://doi.org/10.1016/j. lithos.2018.05.014

Rocha B.C., Moraes R., Möller A., Cioffi C.R., Jercinovic M.J. 2017. Timing of anatexis and melt crystallization in the Socorro-Guaxupé Nappe, SE Brazil: Insights from trace element composition of zircon, monazite and garnet coupled to U-Pb geochronology. Lithos, 277:337-355. https://doi. org/10.1016/j.lithos.2016.05.020

Souza J.D., Kosin M., Heineck C.A., Lacerda Filho J.V., Teixeira L.R., Valente C.R., Guimarães J.T., Bento R.V., Borges V.P., Santos R.A., Leite C.A., Neves J.P., Oliveira I.W.B., Carvalho L.M., Pereira L.H.M., Paes V.J.C. 2004 Folha SD.23 - Brasília. In: Schobbenhaus C., Gonçalves J.H., Santos J.O.S., Abram M.B., Leão Neto R., Matos G.M.M., Vidotti R.M., Ramos M.A.B., Jesus J.D.A. de (eds.). Carta Geológica do Brasil ao Milionésimo. Programa Geologia do Brasil. Brasília: CPRM. CD-ROM.

Spear F.S. 1993. Metamorphic phase equilibria and pressure-temperature-time paths. Washington, D.C., Mineralogical Society of America, 789 p.

Taylor-Jones K., Powell R. 2015. Interpreting zirconium-in-rutile thermometric results. Journal of Metamorphic Geology, 33(2):115-122. https://doi.org/10.1111/jmg.12109

Tedeschi M.F., Novo T., Azevedo R., Amaral L.F.S., Degler R., Viera P.L.N.C.R. 2015. Geologia das Folha Caldas (SF.23-V-D-IV) e Poços de Caldas (SF.23-V-C-VI) 1:100.000. Projeto Fronteiras de Minas. Belo Horizonte: CODEMIG-UFMG

Tedeschi M.F., Pedrosa-Soares A., Dussin I., Lanari P., Novo T., Pinheiro M.A.P., Lana C., Peters C. 2018. Protracted zircon geochronological record of UHT garnet-free granulites in the Southern Brasília orogen (SE Brazil): Petrochronological constraints on magmatism and metamorphism. Precambrian Research, 316:103-126. https://doi.org/10.1016/j. precamres.2018.07.023

Tomkins H.S., Powell R., Ellis D.J. 2007. The pressure dependence of the zirconium-in-rutile thermometer. Journal of Metamorphic Geology, 25(6):703-713. https://doi.org/10.1111/j.1525-1314.2007.00724.x

Tracy R.J., Robinson P., Thompson A.B. 1976. Garnet composition and zoning in the determination of temperature and pressure of metamorphism, central Massachusetts. American Mineralogist, 61 (7-8):762-775.

Trouw R.A.J., Heilbron M., Ribeiro A., Paciullo F.V.P., Valeriano C.M., Almeida J.C.H., Tupinambá M., Andreis R.R. 2000. The central segment of Ribeira Belt. In: Cordani U.G., Milani E.J., Thomaz-Filho A., Campos D.A. (eds.). Tectonic Evolution of South America. 31st International Geological Congress. Rio de Janeiro, p. 287-310.

Trouw R.A.J., Peternel R., Ribeiro A., Heilbron M., Vinagre R., Duffles, P., Trouw C.C., Fontainha M., Kussama H.H. 2013. A new interpretation for the interference zone between the southern Brasília belt and the central Ribeira belt, SE Brazil. Journal of South American Earth Sciences, 48:43-57. http://dx.doi.org/10.1016/j.jsames.2013.07.012
Valente C.R., Lacerda Filho J.F., Rizzotto G.J., Lopes R.C., Romanini S.J., Oliveira I.W.B., Sachs L.L.B., Silva V.A., Batista I.H. 2004. Folha SE.22 Goiânia. In: Schobbenhaus C., Gonçalves J.H., Santos J.O.S., Abram M.B., Leão Neto R., Matos G.M.M., Vidotti R.M., Ramos M.A.B., Jesus J.D.A. de (eds.). Carta Geológica do Brasil ao Milionésimo. Programa Geologia do Brasil. Brasília: CPRM. CD-ROM.

Valeriano C.M. 2017. The Southern Brasília Belt. In: Helibron M., Cordani U.G., Alkmim F.F. (eds.). São Francisco Craton, Eastern Brazil - Tectonic Genealogy of a Miniature Continent. Regional Geology Reviews. Berlin / Heidelberg: Springer, p. 189-203.

Valeriano C.M., Dardenne M.A., Fonseca M.A., Simões L.S.A., Seer H.J. 2004. A evolução tectônica da Faixa Brasília. In: Mantesso-Neto V., Bartorelli A., Carneiro C.D.R., Brito Neves B.B. (eds). Geologia do Continente SulAmericano: evolução da obra de Fernando Flávio Marques de Almeida. São Paulo: Beca, p. 575-592.

Valeriano C.M., Pimentel M.M., Heilbron M., Almeida J.C.H., Trouw R.A.J. 2008. Tectonic evolution of the Brasília Belt, Central Brazil, and early assembly of Gondwana. In: Pankhurst R.J., Trouw R.A.J., Brito Neves B.B. De Wit M.J. (eds.). West Gondwana: Pre-Cenozoic Correlations Across the South Atlantic Region. London: Geological Society, Special Publications, 294(1), p. 197-210. https://doi.org/10.1144/SP294.11

Vinagre R., Trouw R.A., Mendes J.C., Duffles P., Peternel R., Matos G. 2014. New evidence of a magmatic arc in the southern Brasilia Belt, Brazil: the Serra da Agua Limpa batholith (Socorro-Guaxupé Nappe). Journal of South American Earth Sciences, 54:120-139. https://doi.org/10.1016/j. jsames.2014.05.002

Vlach S.R., Gualda, G.A.R. 2000. Microprobe monazite dating and the ages of some granitic and metamorphic rocks from southeastern Brazil. Revista Brasileira de Geociências, 30(1):214-218.

Whitney D.L., Evans B.W. 2010. Abbreviations for names of rock-forming minerals. American Mineralogist, 95(1):185-187. https://doi.org/10.2138/ am.2010.3371

Woodsworth G.J. 1977. Homogenization of zoned garnets from pelitic schists. The Canadian Mineralogist, 15(2):230-242.

Yardley B.W.D. 1977. An empirical study of diffusion in garnet. American Mineralogist, 62(7-8):793-800.

Zack T., Moraes R., Kronz A. 2004. Temperature dependence of Zr in rutile: Empirical calibration of a rutile thermometer. Contributions to Mineralogy and Petrology, 148(4):471-488. http://dx.doi.org/10.1007/ s00410-004-0617-8

Zanardo A. 1992. Análise petrográfica, estratigráfica e microestrutural da região de Guaxupé-Passos-Delfinópolis (MG). PhD Thesis, Instituto de Geociências e Ciências Exatas, Universidade Estadual Paulista "Júlio de Mesquita Filho", Rio Claro, $288 \mathrm{p}$

Zanardo A. 2003. Pesquisa Geológica e de matérias primas cerâmicas do centro nordeste do Estado de São Paulo e vizinhanças - Sistematização crítica da produção Técnico - Científica. $\mathrm{PhD}$ Thesis, Instituto de Geociências e Ciências Exatas, Universidade Estadual Paulista "Júlio de Mesquita Filho", Rio Claro, 304 p.

Zanardo A., Morales N., Oliveira M.A.F., Del Lama E.A. 2006. TectonoLithologic associations of the Alterosa Paleo Suture Zone - Southeastern Brazil. Revista UnG - Geociências, 5(1):103-117. 